\title{
Universiteit
}

Leiden

The Netherlands

\section{Languages of the Middle Andes in areal-typological perspective: Emphasis on Quechuan and Aymaran}

Adelaar, W.F.H.; Campbell L., Grondona V.M.

\section{Citation}

Adelaar, W. F. H. (2012). Languages of the Middle Andes in areal-typological perspective: Emphasis on Quechuan and Aymaran. In G. V. M. Campbell L. (Ed.), The Indigenous Languages of South America. A Comprehensive Guide. (pp. 575-624). Berlin; Boston: De Gruyter Mouton. doi:10.1515/9783110258035

Version: $\quad$ Not Applicable (or Unknown)

License: $\quad$ Leiden University Non-exclusive license

Downloaded from: https://hdl.handle.net/1887/70116

Note: To cite this publication please use the final published version (if applicable). 


\title{
Languages of the Middle Andes in areal-typological perspective: Emphasis on Quechuan and Aymaran
}

\author{
Willem F.H. Adelaar
}

\section{Introduction 1}

Among the indigenous languages of the Andean region of Ecuador, Peru, Bolivia, northern Chile and northern Argentina, Quechuan and Aymaran have traditionally occupied a dominant position. Both Quechuan and Aymaran are language families of several million speakers each. Quechuan consists of a conglomerate of geographically defined varieties, traditionally referred to as Quechua "dialects", notwithstanding the fact that mutual intelligibility is often lacking. Present-day Aymaran consists of two distinct languages that are not normally referred to as "dialects". The absence of a demonstrable genetic relationship between the Quechuan and Aymaran language families, accompanied by a lack of recognizable external genetic connections, suggests a long period of independent development, which may hark back to a period of incipient subsistence agriculture roughly dated between 8000 and 5000 BP (Torero 2002: 123-124), long before the Andean civilization attained its highest stages of complexity.

Quechuan and Aymaran feature a great amount of detailed structural, phonological and lexical similarities and thus exemplify one of the most intriguing and intense cases of language contact to be found in the entire world. Often treated as a product of long-term convergence, the similarities between the Quechuan and Aymaran families can best be understood as the result of an intense period of social and cultural intertwinement, which must have pre-dated the stage of the proto-languages and was in turn followed by a protracted process of incidental and locally confined diffusion. It stands to reason to assume that the initial interaction between the two language groups took place within a relatively limited geographical space, which may have been situated in the mountains and sections of the coast of Central Peru. It may have extended as far north as the department of Ancash, with its influential archaeological center at Chavin (1st millennium BC), and southward into the highlands of Ayacucho and along the Pacific coast, where the Pre-Columbian cultures of Paracas ( \pm 600 BC-200 AD) and Nazca ( $\pm 200-700$ AD) flourished. In this central Peruvian area, there are few traces of indigenous languages not belonging to the Quechuan and Aymaran families, in spite of recurrent reports of multilingualism in early colonial chronicles. Possibly, the impression of multilingualism among colonial observers is to be interpreted as a reflection of linguistic variation 
within the Quechuan and Aymaran families themselves, although this partly remains a matter of speculation. Other languages native to the Andean region were

\section{camp_010.pod 576}

\section{7-10-12 14:21:11 -mu- mu}

576 Willem F.H. Adelaar

mainly found at the northern and southern peripheries of the Quechuan-Aymaran domain. Most of these groups have succumbed to the direct or indirect pressure of the two major indigenous language families or to Spanish, the language of the European colonizers who conquered the area in 1532. The Andean region as delineated at the beginning of this introduction represents an area with an originally high genetic diversity that achieved an apparent uniformity through the dominance of just a few of its endemic language groups (Quechuan and Aymaran) and an intrusive language (Spanish).

The geographical area covered by this chapter on Andean languages is henceforth referred to as the Middle Andes.2 It roughly coincides with the boundaries of the Inca Empire (Tawantinsuyu) in its final stage ( $\pm 1470-1532$ ), and also with the maximal expansion of the Andean civilization. This civilization was based on an age-old cultural and economic interaction which had its roots in north-central Peru in the 3rd millennium before our era.3 Areas further to the north and south, such as Ecuador, Colombia, central and southern Chile, as well as most of Argentina, did not play a significant part in these early developments. At the time of the Spanish conquest, however, the Andean and coastal regions of Ecuador, and northern Chile, as well as the Andes of Bolivia and northwestern Argentina were firmly integrated within a Middle-Andean area of socio-political and cultural interaction.

To the east, most of the Middle Andes is confined by the Amazonian region, the eastern Bolivian lowlands and the Gran Chaco. From an ethnographic point of view, the boundaries with these areas are diffuse. It is therefore useful to include some discussion of the languages spoken in these transitional areas in an overview of Middle Andean languages.

The purpose of the present chapter is to explore the typological profile of Quechuan and Aymaran, as well as the typological environment in which these language families have been situated over time, both from a historical and from a spatial perspective. In the absence of demonstrable genetic relationships, a comparison of the typological characteristics of the languages of the Middle Andes 
with those of their neighbors and former neighbors can provide an insight into the contact history that may have contributed to their formation. Understandably, at this exploratory stage, it will not be possible yet to reach firm conclusions, so this chapter will retain the character of a first inventory. Our exploration has the following structure: It starts with an overview of the Andean languages and the languages of surrounding areas with which they may have been in contact for geographical reasons (Section 2). Secondly, a brief sketch is given of the historical developments that are important for understanding the language situation in the Middle Andes (Section 3). Some issues concerning genetic classification and linguistic diffusion that are relevant to the Middle Andean situation are discussed in Section 4, and an interpretative model of Quechuan-Aymaran contact history is briefly introduced in Section 5. The subsequent sections deal with particular aspects that are characteristic of the (non-genetic) relationship that exists between

\section{camp_010.pod 577}

\section{7-10-12 14:21:11 -mu- mu}

Languages of the Middle Andes in areal-typological perspective 577

Quechuan and Aymaran: structural similarities (Section 6), structural differences (Section 7), phonological coincidence (Section 8), and lexical overlap (Section 9). Issues in which possible typological relations external to the Quechuan-Aymaran complex are involved are treated in the sections Section 10 (phonological features) and Section 11 (morphosyntactic features). Finally, section Section 12 deals with some external typological relations that involve Andean languages other than Quechuan and Aymaran.

\section{Overview of the languages}

Considering the internal diversification of each group, both Quechuan and Aymaran have to be treated as language families, rather than as single languages. This fact is only partly reflected in the current terminology. The Aymaran family comprises at least two living languages. One of them is Aymara, spoken by more than 2,000,000 people in Bolivia (departments of La Paz, Oruro, Cochabamba and Potosi), in southern Peru (departments of Moquegua, Puno and Tacna) and in northern Chile (region of Tarapaca). Dialect diversity within the Aymara language area is believed not to exceed the level of mutual intelligibility, but much research remains to be done in this field.

The other extant Aymaran language is Jaqaru, spoken in the village of Tupe and neighbouring hamlets in the province of Yauyos (department of Lima, Peru) by 
somewhat more than a 1000 people. A third variety, Cauqui (Kawkı), is spoken by a few elderly people in the village of Cachuy, not far from Tupe. It is treated as a separate language by Hardman $(1978,2000: 1)$ but is reported to be only dialectally different from Jaqaru by Cerron-Palomino (2000: 63-65). Aymara and Jaqaru differ considerably and their status as separate languages is not in doubt. The two languages are also referred to as Southern Aimara and Central Aimara, respectively (Cerron-Palomino 2000).

Apart from Aymara and Jaqaru, the Aymaran language family must have comprised a number of extinct varieties, whose existence can be inferred from mentions in historical sources and from toponymy. Such extinct varieties were found in the southern highlands of Peru (departments of Ayacucho, Arequipa, Cuzco, etc.) and in the highlands of the department of Lima. Torero (2002: 129) observes that some of these varieties were not recognized as Aymaran by the authors who mention them.4 They may have been significantly different from the language underlying modern Aymara, to which Torero assigns a homeland situated near Vilcashuaman in the basin of the Rio Pampas at the boundary between the Peruvian departments of Ayacucho and Apurimac. This predecessor of present-day Aymara would have expanded southward in a very short time, replacing other languages, both related and unrelated. In the 16th century, Aymara covered most of the Bolivian highlands, including large areas in the departments of Cochabamba, Oruro,

\section{camp_010.pod 578}

\section{7-10-12 14:21:11 -mu- mu}

578 Willem F.H. Adelaar

Potosi and Sucre that are now Quechua-speaking. The Aymaran family has alternatively been referred to as Jaqi (Hardman 1978, 1985) and as Aru (Torero 1970, 2002).5

The internal diversification of the "Quechua" language group justifies its qualification as a language family within the same right as Aymaran. It comprises a large variety of dialects, spoken by a totality of some $8,000,000$ speakers. On the basis of mutual intelligibility tests carried out in the 1970s, Torero (2002: 85) recognizes the existence of at least seven Quechua "languages", all of them dialectally diversified. However, there is a firmly established tradition of referring to all Quechuan varieties as "dialects", mostly identified by the name of the region or community where they are spoken (e.g. Cajamarca Quechua, Cuzco Quechua, 
Pacaraos Quechua, etc.). Only a few varieties are known by specific names, for instance, Huanca for the variety of the Mantaro valley in Peru, Lamista for the variety of the area of Lamas in the department of San Martin, Peru), Inga(no) for Colombian Quechua, Cuzco for the Santiago del Estero variety spoken in Argentina, Quichua for the Ecuadorian varieties but also for several other varieties in Argentina and Peru. The use of the denomination "Quechuan", with the ending '-(a) $n$ ', has not been common, mainly because there is no particularly variety of Quechuan more entitled to be called "Quechua" than any of the others. The name Quechuan, nevertheless, is useful for distinguishing reference to the whole family of Quechuan varieties (languages and dialects) from the use of "Quechua" in reference to individual varieties. It should be observed that the variety of Cuzco is thought to represent the "official" version of Quechua by most of its speakers and by the Cuzco-based Quechua Language Academy (Academia Mayor de la Lengua Quechua). In the perspective of that institution, an inferior status of "mixed" or "corrupt" dialects is often attributed to all the remaining varieties of Quechuan. A majority of the Quechuan varieties have been assigned to two main branches (Parker 1963; Torero 1964). The differences between these branches are more or less comparable to those existing between the two languages that make up contemporary Aymaran. However, not all the Quechuan varieties can be easily accommodated within either of the two branches, and some authors prefer to speak of a dialect continuum that covers all the varieties of central and southern Peru (e.g. Heggarty 2005). The two branches of Quechuan are known as Quechua $A$ and Quechua B (Parker 1963), or as Quechua I/ and Quechua I(Torero 1964), respectively. Torero further divided Quechua II into three subgroups: Quechua IIA, Quechua IIB and Quechua I/C.6 Quechua I (or B) is spoken in the highlands of central and central-northern Peru, in the departments of Ancash, Huanuco, Lima, Junin and Pasco, and in a few localities in the departments of Huancavelica, Ica and La Libertad. In the middle of the 20th century, this Quechua I area was more or less continuous, but it is now seriously affected by language attrition at the local level (Chirinos Rivera 2001). Apart from a divergent lexical basis, the unique character of the Quechua I group rests upon a series of sequenced morphological innoCamp_

\section{0.pod 579}

\section{7-10-12 14:21:11 -mu- mu}

Languages of the Middle Andes in areal-typological perspective 579 
vations, some of them initially triggered by phonological change. In a few cases, such innovations have affected the transparent agglutinative structure preserved in most varieties of Quechuan.

The Quechua II (or A) group comprises all the remaining varieties of Quechuan. The Quechua IIB varieties are located mostly to the north and northeast of the Quechua I group. They comprise all the Quechuan varieties of Ecuador (Highland Ecuadorian Quichua and Lowland Ecuadorian Quichua) and Colombia (Inga or Ingano) and, in Peru, the variety of Lamas in the department of San Martin (Lamista), that of Chachapoyas in the department of Amazonas, several varieties spoken in the Amazonian region and an extinct variety that was used around Lima in the 16th century. Torero (2002: 132-139) reports that Quechua IIB, or a related type of Quechuan, was also widely used along the coast and in the Andes of southern Peru before it was eventually replaced by Quechua IIC. This variety (if not several) is usually associated with the port city of Chincha, but its historical presence is also attested in the southern sections of the Andean departments of Ayacucho and Huancavelica.

The Quechua IIC group comprises some of the most vital varieties spoken today, such as those of Ayacucho (in the departments of Ayacucho, Huancavelica, and parts of Apurimac and Arequipa) and Cuzco (in the departments of Cuzco, Puno and parts of Apurimac, Arequipa and Moquegua), and all the varieties spoken in Bolivia and Argentina, as well as possibly Chile, where the presence of a native Quechua is but weakly attested. The Argentine variety of Santiago del Estero deserves a special mention because it is spoken by a highly mixed population, in a lowland province isolated from the remainder of a Quechuan-speaking continuum covering eastern and southern Bolivia and (until formerly) the Andean sector of northwestern Argentina.

Quechua IIA is a controversial subgroup considering that both its internal coherence and its assignment to Quechua II have been questioned (Taylor 1984; Landerman 1991; Heggarty 2005). Quechua IIA varieties are found in northern Peru, in the province of Ferrenafe (department of Lambayeque) and in the provinces of Cajamarca and Hualgayoc (department of Cajamarca). Other varieties that have been attributed to Quechua IIA are (or were) found on the Pacific slopes of the central Peruvian Andes, in the provinces of Huaral and Yauyos in the department of Lima.

Recent research (Adelaar, forthcoming) suggests that the Quechua IIA variety 
of Cajamarca and those of Laraos and Lincha in the province of Yauyos may represent separate splits from a putative Proto-Quechua II, which was probably centered around the modern town of Ayacucho. The Quechua of Ferrenafe appears to be a mixed variety in that it combines elements of Cajamarca Quechua and Quechua I. The variety of Pacaraos in the province of Huaral is akin to Quechua I, rather than to Quechua II, and was influenced by an unidentified Aymaran language.

\section{camp_010.pod 580}

\section{7-10-12 14:21:11 -mu- mu}

580 Willem F.H. Adelaar

The Quechuan languages with the largest numbers of speakers today are Ayacucho Quechua, Cuzco Quechua (including Puno), Southern and Eastern Bolivian Quechua (all Quechua IIC), Ecuadorian Highland Quichua (Quechua IIB, with several local sub-varieties) and Ancash Quechua (Quechua I). These are the varieties of Quechuan with the best prospects for an eventual survival.

At the northern end of the Quechua I continuum, the area of Quechuan predominance ends abruptly. An unrelated language, known as Culli or Culle, was spoken in the northern part of the department of Ancash (in the province of Pallasca, possibly also in some parts of the provinces of Corongo and Sihuas), in the department of La Libertad (to the west of the Maranon river except for the coastal region), and in the province of Cajabamba (department of Cajamarca). Speakers of Culli were last reported in the town of Tauca (province of Pallasca) around 1950 (Manuel Flores Reyna, personal communication). Only a few short word-lists were recorded for this language, but its toponymy is abundant and requires further research. In the colonial time, the use of a variety of Quechuan in the Culli area and further north was probably limited to urban centers, such as Cajamarca and Huamachuco, including their immediate environs.

The possibility of a further extension of Culli into the western provinces of the department of Cajamarca is in debate. There is a shared lexical substratum between the Quechuan variety spoken in Chetilla (to the west of Cajamarca in the province of the same name) and the Spanish spoken in the province of Santiago de Chuco (La Libertad), which seems to argue in favor of such an extension (Adelaar with Muysken 2004: 403-404). By contrast, Torero (1989) assigns the area in which Chetilla is situated to a hypothetical language denominated Den after its most characteristic toponymical ending. Luis Andrade Ciudad (2009, personal communication) 
recognizes three consecutive pre-Spanish linguistic layers in western Cajamarca, "Den”, Culli and Quechuan. The oldest layer (Den) is characterized by the absence of hybrid place names. By contrast, hybrid place names, including those combining lexical material from different indigenous languages and/or Spanish, are abundant in the area of Culli influence, for instance, Agallpampa 'child plain' (Culli-Quechuan) and Cruzmaca 'hilly of the Cross' (Spanish-Culli). A small language family comprising two languages, Cholon and Hibito, was located to the east of the Culli area, between the valleys of the Huallaga and the Maranon. The historical Cholon were established in the Huallaga valley north of Tingo Maria, the Hibito on one of its tributaries, the Huayabamba. The Cholon language survived until late in the 20th century. Although it was recorded in a transitional lowland setting, the missions of the Huallaga valley, its territory may have extended well into the Andes. The toponymy of parts of eastern Cajamarca suggests a connection with Cholon, for instance, in Salcot 'black water' (Cholon tsal 'black', kot 'water') and in Llacanora, which seems to contain the Cholon root lyaka ('red'). This area coincides with the domain of another hypothetical language proposed by Torero, the Cat language (Torero 1989: 236-237). The high mountain

\section{camp_010.pod 581}

\section{7-10-12 14:21:11 -mu- mu}

Languages of the Middle Andes in areal-typological perspective 581

ranges of eastern La Libertad, beyond the Maranon, may also have been Cholonspeaking areas. Although Cholon only became extinct a few decades ago, its main documentary basis, a missionary grammar, dates from the 18th century (AlexanderBakkerus 2005, 2007).

In the Andean highlands of the department of Amazonas, near the town of Chachapoyas, a separate language, called Chacha, existed. Only names persist of this language with its very characteristic phonology (Taylor 1990; Schjellerup et al. 2003: 7-8, 246-247). According to a sixteenth century document included in the Relaciones Geograficas de Indias (Jimenez de la Espada 1965, III: 143-146), a group of distinct languages were spoken in an area surrounding the bend of the Maranon. Three of these languages (Copallen, Sacata, Tabancale) were spoken in highland or slightly elevated areas. The Bagua language was spoken at the bottom of the valley of the Maranon and its nearby tributaries, as well as Patagon, a Cariban language, and several languages of the Candoshian language family. All these 
languages disappeared early in the colonial period and their documentation remains limited to a few words. Only a representative of the Candoshian language family (Shapra or Murato) survives.

In the coastal region of the Peruvian departments of Ancash, La Libertad and Lambayeque two languages shared the domain of the former kingdoms of Lambayeque and Chimu: Mochica and Quingnam. A third language mentioned in the sources, la lengua pescadora ('language of the fishermen'), may have been a dialect or a social variant of Quingnam (Torero 1986). Its existence may reflect an age-old dichotomy between coastal fishermen and desert valley farmers in northern Peru. Quingnam was spoken near Trujillo and along the coast in southern direction. It disappeared so soon after the conquest that for a long time its sheer existence was held in doubt.8 The dynastic names of the Chimu rulers, which have been preserved, indicate that Quingnam was neither identical to Culli, nor to Quechuan (Zevallos Quinones 1992). The denomination Mochica (also called Muchik or Yunga) has been assigned to a language that was spoken in the neighbourhood of Chiclayo and Lambayeque until the middle of the 20th century. It is relatively well documented thanks to a seventeenth century grammar (Carrera Daza [1644] 1939), augmented with data collected at the end of the 19th century and at the beginning of the 20th century (Middendorf 1890; Salas 2002), shortly before the language became extinct. The boundary between the Mochica and Quingnam languages, with some overlap, must have been situated in the valley of the coastal Jequetepeque or Pacasmayo river.9 At a certain stage, the Mochica linguistic area extended into the departments of Cajamarca (to the east) and Piura (to the north). Mochica is known for its immunity to Quechuan influence and its extreme typological divergence from other languages spoken in the Andean region, which makes its origin an object of speculation.

At least two languages were spoken in the coastal region of the department of Piura until the nineteenth century. Although a relatively large descendant popuCamp_

\section{0.pod 582}

\section{7-10-12 14:21:11 -mu- mu}

582 Willem F.H. Adelaar

lation survives, these languages, sometimes collectively referred to as $\mathrm{Sec}$, have become extinct. As in the case of Mochica, a rich array of place names and family names have been preserved and await closer investigation. The Sechura language 
was spoken near the port of Sechura, while the Tallan language (its varieties also known as Colan and Catacaos) was used in the Chira and Piura valleys. The language of the desert oasis of Olmos further south may have been a dialect or a manipulated variety of Sechura (Torero 1986). Little is known about the original languages of the (hispanicized) Andean interior of Piura. It may have harbored varieties of Quechuan as well as an unidentified local language.

A series of extinct languages was spoken in the intra-Andean valleys of Ecuador, from south to north: Palta and Malacato and several other languages (in the province of Loja), Canar (in the provinces of Azuay, Canar and Chimborazo south of the town of Alausi), Puruha (mainly in the province of Chimborazo with its central town of Riobamba), Panzaleo (in the provinces of Pichincha, Cotopaxi and Tungurahua, between Quito and the town of Mocha), Cara, Caranqui or Otavalo (in the province of Imbabura and in that of Pichincha, north of Quito), and Pasto (north of the Cara, in the province of Carchi and straddling the border between Ecuador and Colombia). All these languages presumably became extinct in the eighteenth century (Pasto probably later). Canar, Puruha, Panzaleo and Cara were replaced by varieties of Quechuan, the others by Spanish with a possible Quechuan interlude. Voluminous toponym data from all these languages were collected by Jijon y Caamano (1940-1945) and Paz y Mino (1940-1942, 1961).

There are indications that the Palta and Malacato languages may have been related to the Jivaroan languages, a thriving group of languages spoken in the Amazonian border region of Ecuador and Peru (Gnerre 1975). If this is true, the possibility that the Jivaroan peoples (Aguaruna, Shuar, Achuarand Huambisa) may have had an Andean origin cannot be excluded. As we shall see, this is not unlikely at all from a typological point of view. Although the documentation is scarce, the Cara and Pasto languages seem to have belonged to the Barbacoan language family with three living representatives in the Pacific lowlands and slopes of northern Ecuador (Cha'palaachi or Cayapa, Tsafiki or Colorado, Awa Pit or Cuaiquer). The Barbacoan family extends into Colombia, where the Guambiano language is an outlying representative (Curnow and Liddicoat 1998). For Panzaleo, Puruha and Canar no connection with any surviving language could be established, although the structure and the shape of toponyms suggest that the latter two languages may have been related to each other.

Coastal Ecuador (except for its northernmost part) became rapidly hispanicized after the Spanish conquest. As a result, almost nothing is known about the languages 
of that important and long-settled area. The Huancavilca people of Guayaquil (province of Guayas) and the area to the west of it must have had their own language, as did the inhabitants of the island of Puna, who had hardly been subdued by the Incas. The area of Manta and Portoviejo (province of Manabi) was reCamp_

\section{0.pod 583}

\section{7-10-12 14:21:11 -mu- mu}

Languages of the Middle Andes in areal-typological perspective 583

ported to be multilingual. In the northern part of the coastal region, the language of Esmeraldas and Atacames (province of Esmeraldas) continued to be used by an Africanized population until the end of the 19th century. It does not show any affinity with other languages, but it exhibits heavy borrowing from the neighboring Barbacoan languages, Tsafiki in particular. This may be an indication that a large population called the Chonos, as well as other ethnic groups that originally inhabited the interior of the Ecuadorian coastal plain, may have been Barbacoan speakers as well, and that the speakers of modern-day Tsafiki are part of their descendants. Furthermore, little is known about the linguistic identity of several groups (Yumbo, Quijo) that inhabited the Andean high slopes to the west and east of the Imbabura highlands in northern Ecuador.

In southern Peru, in an area now mainly covered by Cuzco and Puno Quechua, the Puquina language was spoken until the beginning of the 19th century. Its exact area of dispersal is not known, but many place names in the departments of Arequipa, Moquegua, Puno and Tacna are indicative of Puquina presence. In addition, Puquina was spoken in parts of the Bolivian highlands, in particular, north of Lake Titicaca, and in the proximity of the modern town of Sucre. In the 16th century, it was accorded the status of one of the three "general languages" of Peru (together with Quechua and Aymara) by the Spanish authorities. Puquina combines elements of the Amazonian Arawakan family with typically Andean (Quechuanlike) features. It may have preceded the Aymara language in its present stronghold to the south and east of Lake Titicaca, hence it may have been associated with the civilization of Tiahuanaco, centered in that area during the first millennium of the present era ( $\pm 500-1100$ AD). Puquina vocabulary survives in the core lexicon of Callahuaya, a professional language used by medicinal herb specialists from the area of Charazani, north of Lake Titicaca, in the department of La Paz (Bolivia). Callahuaya is reasonably well documented, but our knowledge of Puquina depends 
on a limited collection of translated religious texts (Ore 1607). For sketches of Puquina, see Torero $(1987,2002)$ or Adelaar and van de Kerke (2009).

The languages of the Uru-Chipayan family and their speakers have long been associated with aquatic environments, such as the shores and islands of Lake Titicaca and Lake Poopo (Bolivia). According to early colonial chroniclers, their domain extended downward to the Pacific coast, and they may have been associated with the extinct Chango population of fishermen on what is now the northern Chilean coast. Practically nothing is known of the language spoken by the Changos, so that their linguistic affiliation cannot be determined.

The lifestyle of part of the Uru-Chipayan peoples was distinctly non-agrarian, which earned them a special social status. Today, the Chipaya language is spoken by several thousand people in Santa Ana de Chipaya, an isolated highland village in the province of Carangas (department of La Paz, Bolivia), close to the Chilean border, and by migratory workers. The Uchumataqu or Uru language of Irohito, in Bolivia, near the southern shore of Lake Titicaca close to the Peruvian border, is

\section{camp_010.pod 584}

\section{7-10-12 14:21:11 -mu- mu}

584 Willem F.H. Adelaar

moribund. There are no speakers left of the Uru language of Ch' imu, which was still used near Chucuito (Peru) in the 1930s. Traces of another possible Uru-Chipayan language have been recorded in Bolivia among the Murato people in the area of Lake Poopo (Schumacher et al. 2009). The Murato share the characteristic culture and lifestyle of the Urus of lake Titicaca. For recent overall studies of Chipaya and Uchumataqu see Cerron-Palomino (2006) and Hannss (2008), respectively. The Atacameno or Kunza language (also called Lican Antal) was spoken until around 1900 in San Pedro de Atacama and neighbouring desert oases, located east of Calama, in the province of Antofagasta in northern Chile. Toponymy suggests an erstwhile further extension of this language into Argentina and Bolivia, though it apparently did not reach the Chilean coast. Although a vocabulary of the Atacameno language has been preserved (Vaisse et al. 1896), the information on its phonological and grammatical features is only fragmentary. The identity of the Humahuaca language, once spoken to the east of Atacameno, in the Quebrada de Humahuaca, is still unclear.

Diaguita or Cacan was the language of an important indigenous population 
that was originally divided over northern Chile (provinces of Atacama and Coquimbo) and northwestern Argentina (provinces of Salta, Tucuman, Catamarca and La Rioja). Most of the Argentine Diaguita were deported after a rebellion in the 17th century, which put an end to the survival of their language. Tonocote was spoken in a lowland area near Tucuman and Santiago del Estero. Its relation to the Lule language, of which an 18th century grammar (Machoni 1732) exists, is unclear. 10 In the first half of the 18th century, Lule speakers from the Chaco area had been concentrated in a number of townships near Tucuman (Furlong 1941). Lule forms a small family of languages together with the highly moribund Vilela language of the Argentinian Gran Chaco (Viegas Barros 2001). Historical documents report that 16th century grammars of Diaguita and Tonocote once existed, but they appear to be irremediably lost.

Further to the south, at the far reaches of the Inca empire, the Araucanian language was spoken in its northern dialect variety (Mapocho, Picunche) in the region of present-day Santiago de Chile. Speakers of Huarpean, a small extinct family of languages (Allentiac, Millcayac) were found in the present-day Argentine provinces of Mendoza and San Luis. All these languages are fairly well documented thanks to the work of the missionary grammarian Luis de Valdivia (1560-1642). There is, furthermore, an extensive literature on Araucanian and its main modern descendent, called Mapuche or Mapudungun (Salas 1992; Zuniga 2000; Smeets 2007). The Araucanian language group has no external genetic relatives as far as is known.

As we have seen, the eastern boundaries of the Middle Andean area are fluid.

These eastern slopes harbor an extraordinary variety of often unrelated languages. A full inventory of the languages found in this region falls outside the scope of the present chapter, but one must take into account that some of them have had close

\section{camp_010.pod 585}

\section{7-10-12 14:21:11 -mu- mu}

Languages of the Middle Andes in areal-typological perspective 585

historical connections with the Andean languages. As we noted before, this was the case of the Cholon-Hibitoan, Candoshian and Jivaroan languages. In the northern sector (Colombia and northern Ecuador), the western branch of the Tucanoan languages has been in intermittent contact with Andean languages, and so has Zaparoan further south. The isolate Cofan in the Colombian-Ecuadorian border area 
may also have had Andean connections. Among the more isolated groups of eastern Ecuador we may mention the Huaurani and their language.

Among the pre-Andine groups of northern Peru, we may furthermore mention the Cahuapanan family (comprised of the Jebero and Chayahuita languages), which is structurally not unlike the major Andean languages, and (nearly extinct) Muniche. Urarina, Omurano (extinct), Peba-Yaguan, Taushiro, Ticuna, Vacacocha ( Tequiraca), Boran and Huitotoan (the latter two probably related) occupy areas further away from the Andes. The Cocamalanguage with a strong basis of Tupi-Guaranian is spoken by descendents of a nation that used to hold a commercial key position along the Amazon River and its tributaries. This language contains components from different origins (Cabral 1995, 2007).

The Arawakan language family is widely dispersed over South America and the Caribbean islands, and it can therefore not be qualified as a typically Andean group. However, the Arawakan languages spoken in central Peru on the eastern slopes of the Andes exhibit many signs of interaction with Andean languages, the Amuesha or Yanesha'language being the most extreme example of such contacts (Wise 1976; Adelaar 2006). Originally established in the Oxapampa valley (department of Pasco, Peru) at an average altitude of 1800 meters, the Amuesha underwent such a profound transformation of their culture and language under the influence of speakers of neighboring Quechua I that it would only be fair to treat their language as a Middle Andean language. The borrowed lexicon in Amuesha includes more than 60 Quechuan verb roots, among other items. The neighboring Campan languages (Asheninka, Ashaninka, Caquinte, Nomatsiguenga, Matsiguenga, Nanti), a subgroup of Arawakan, are not free of Andean influence either.

The existence of an inclusive-exclusive first person plural pronominal distinction may be attributed to it (Danielsen, forthcoming). Other Arawakan languages in southern Peru, further away from the Andean foothills, are Yine or Piro, and Inapari. Another important cluster of Arawakan languages (Baure, Moxo, Paunaca, etc.) is located in the Bolivian lowlands.

The Pano-Tacanan languages, composed of two major branches, Panoan and Tacanan, are widely spread over the eastern lowlands of Peru, Brazil and Bolivia (the Tacanan mainly in Bolivia). They also exhibit old Andean contact relations, although less clearly so than the Arawakan languages do. Some Panoan groups, such as the Cashibo-Cacataibo, are almost Andean by their location. By contrast, the independent Harakmbut group, located in the Andean foothills of Madre de 
Dios, appears to be a relatively recent arrival from the Brazilian Amazon, where the Katukina or Kanamari speak a related language (Adelaar 2000).

\section{camp_010.pod 586}

\section{7-10-12 14:21:11 -mu- mu}

586 Willem F.H. Adelaar

The eastern slopes and pre-Andine lowlands of the Bolivian Andes are home to a large number of linguistic isolates, some of which are located so close to the Andes that they must at least be mentioned. This is notably the case of the Leco and Yuracare languages, and the small Mosetenan family. Four other isolates, Canichana, Cayuvava, Itonama and Movima, are somewhat more remote geographically, but they should certainly be taken into consideration when studying the areal connections of the Andean languages. Chiquitano (probably related to the Brazilian Jean languages and other members of the Macro-Jean stock) and Zamucoan may not have had such close contacts with the Andean languages, but Chiriguano (also known as Bolivian Guaranı), a language of the Tupi-Guaranian family and a newcomer to the Andean region, now occupies a part of the eastern slopes. Until around 1800, Chiriguano-speaking tribesmen made several incursions into the Andean highlands, where they are widely remembered and feared. In the area of the Gran Chaco, the Matacoan languages, and to a less direct extent, the Guaicuruan languages, may also be considered (for Lule and Vilela see above).

\section{Historical background}

Seen from the surface, and leaving aside the upheaval caused by the European invasion following the conquest in 1532, the Middle Andes manifests itself as a selfcontained area that proved resistant to linguistic influences from the outside (a possible exception being the rather vague connection of the Puquina language with the Arawakan family). Genetic links between languages of the Middle Andes and those of other areas are rare or deeply hidden. The linguistic diversity found in the Middle Andes appears to be essentially home-grown and the result of an early process of diversification that preceded the rise of the higher stages of Andean civilization (see above). The two main language groups, Quechuan and Aymaran, are both firmly rooted in the Andean world. There are no clear genetic connections with other language families, nor has the alleged genetic relationship between the two groups ever been established beyond reasonable doubt. If such a relationship should exist at all, the moment of separation must have been located so far back in time that it can no longer be demonstrated by normal comparative procedures. In 
the present state of our knowledge, there is also no way to establish if the ancestors of the Quechuan and Aymaran lineages reached the Middle Andean area on separate occasions or in a single migration.

The overall picture has not always been one of stability. Speakers of Quechuan and Aymaran acquired their position of dominance over the centuries, struggling with each other for the same geographical space and pushing the speakers of most other languages into the periphery or into oblivion by assimilation. Two developments were of essential importance: the consecutive (or simultaneous) expansions of Aymaran and Quechuan and the mutual interaction of the two language groups,

\section{camp_010.pod 587}

\section{7-10-12 14:21:11 -mu- mu}

Languages of the Middle Andes in areal-typological perspective 587

which led to one of the most remarkable cases of linguistic convergence in the world.

For both the Quechuan and the Aymaran families, internal diversity indicates a long process of diversification in which the modern varieties developed from two postulated proto-languages. The estimated antiquity of these proto-languages oscillates between 1200 and 1800 years, but the latter figure seems to be more realistic than the former considering that the different varieties of each language group must have influenced each other constantly due to geographic proximity and almost uninterrupted contact. Importantly, the dating of the proto-languages is also relevant for the dating of the first Quechuan-Aymaran convergence, because much of the shared structures and elements must have been acquired at the stage of the proto-languages or before that time.

A question that has occupied many researchers over the years is that of the homeland of both Quechuan and Aymaran. According to a widespread tradition, the Quechuan expansion was assigned to the military conquests of the Incas of Cuzco (ca. 1430-1532), building on the presupposition that Quechua had to be a local language indigenous to the Inca capital and its surroundings. At the same time, Aymara was associated with the altiplano culture of Tiahuanaco (period of expansion \pm AD 600-1000) near the banks of Lake Titicaca. Linguistic maps depicted Central Peru as a blank area filled with unknown or imagined languages (see, for instance, McQuown 1955; Loukotka 1968). Although the idea of a Cuzco-based origin for Quechuan is still widely advocated in 
traditional circles, it must be abandoned in the light of the study of the Quechuan geographical varieties carried out since the 1960s (see above). The present-day distribution of Quechuan varieties clearly points at Central Peru as the homeland of Proto-Quechuan on the basis of the archaic and highly diverse varieties found in that area. Since Aymaran shows clear evidence of a perennial contact with Quechuan (and vice-versa), the homeland of its proto-language must have been adjacent to or overlapping with that of Proto-Quechuan, a conclusion that is reinforced by the Central Peruvian location of one of the Aymaran languages, viz., Jaqaru.

The homeland of Proto-Quechuan may have been situated on the central coast of Peru, in the high Andes of Central Peru, or in the intermediate valleys oriented towards the Pacific coast (the modern department of Lima and the Andean and coastal provinces surrounding it). Naturally, this Quechuan homeland may have included parts of all three sectors. The original split between Quechua I and Quechua II may have coincided with the division between mountains and coast, the former group staying where it had always been, whereas the second group became the basis of a major expansion into two directions, north and south. Quechua IIB expanded towards Ecuador and northern Peru, from where it occupied the course of several Amazonian tributaries. Its initial expansion is associated with Chincha, the principal seaport on the central Peruvian coast before the arrival of the Spaniards,

\section{camp_010.pod 588}

\section{7-10-12 14:21:11 -mu- mu}

588 Willem F.H. Adelaar

and with Pachacamac, a prestigious temple-city located further north near the mouth of the Lurin river.

Torero (2002: 131-135) reports that coastal Quechua IIB also spread towards the southern Peruvian Andes, where it did not survive eventually, as Cuzco Quechua (Quechua IIC) replaced it as the language of prestige. The expansion of the (Quechua IIA) varieties of Cajamarca and Ferrenafe towards northern Peru corresponds to an earlier wave of migration, not necessarily related to trade.

Most recently, a different scenario has emerged as the expansion of Quechuan was attributed to the centralized state of Huari (AD 500-900), with its capital just north of the modern inland town of Ayacucho. Opinions vary as to whether Huari was the homeland of Quechuan as a whole (Beresford Jones and Heggarty, forthcoming; 
Isbell 2009) or of Quechua II alone (Adelaar, forthcoming) with branches extending towards Cajamarca (Cajamarca Quechua), Yauyos (Laraos and Lincha Quechua), the Central Coast (Quechua IIB) and the Southern Peruvian Andes (Quechua IIC). This scenario puts into debate the antiquity of Quechuan presence on the Peruvian coast.

Considering the (reconstructed) location of the Proto-Quechuan homeland, one may of course ask the question whether a direct ancestor of Quechuan could also have been associated with the earlier cultural developments that took place in the same area. In other words, could a form of pre-Proto-Quechuan have been the language of the Chavin archaeological horizon ( \pm 900 BC - 200 BC)? Indeed, the site of Chavin de Huantar, the center of the Chavin culture, was situated in the middle of the mountainous interior of the Quechuan homeland. Its radiation over large parts of the Peruvian coast and Andes is undisputable, as was the relative stability of Central Peru during the period of Chavin cultural supremacy. Torero (2002: 87) ventures the idea that the highly regular structure of Quechuan morphosyntax might have been related to its use as a language of communication between coast and mountains during the first millennium BC A further step would be to relate the Quechuan linguistic lineage to the much more ancient centers on the Peruvian north central coast (Norte Chico) that are in the process of being excavated, such as Caral and Aspero (cf. Mann 2005). Since the beginning of monumental constructions in that area has been dated as early as $5000 \mathrm{BP}$, there may be such a long period to account for that the question of the relation with Quechuan origins becomes an academic one. Nevertheless, these very ancient centers too were situated in the alleged Quechuan homeland.

As for the Aymaran homeland, it must be located in the neighborhood of that of Quechuan in order to explain the rather impressive contact history of the two groups. Since Aymaran expanded mainly into a southward direction, it makes sense to look for a homeland to the south of the Quechuan homeland. The coastal strip of south-central Peru between Canete and Acari, which comprises the archaeological areas of Ica, Paracas and Nazca, has been indicated as a likely location for the Aymaran homeland (Torero 1972; cf. Cerron-Palomino 2000: 281-283). SubCamp_

\section{0.pod 589}

\section{7-10-12 14:21:11 -mu- mu}

Languages of the Middle Andes in areal-typological perspective 589 
sequently, Aymaran would have penetrated the Andean interior into the presentday region of Ayacucho, where it became the language of the newly formed state of Huari (see above), which during the so-called Middle Horizon competed as a center of power with Tiahuanaco on the Bolivian altiplano. As we have seen, Huari has also been associated with the expansion of Quechuan. Even so, both Quechuan and Aymaran were present in the department of Ayacucho, which constituted a mosaic of languages (cf. Mannheim 1991: 43-47).

Sixteenth century sources, in particular the Relaciones Geograficas de Indias of 1586 (Jimenez de la Espada 1965), mention a multitude of local languages (the so-called hahuasimi of the area of Lucanas, the language of Chumbivilcas, the Cundilanguage of highland Arequipa and (uzco), which are identified by Torero (2002: 128-131) as extinct languages belonging to the Aymaran family. They can all be considered remnants of a gradual process of Aymarization that affected the southern Peruvian highlands during the first millennium AD, although of course the survival into the 16th century of other native language groups (in addition to Puquina) cannot be excluded. Specific Aymaran features to be found in the Quechua I varieties suggest that particular Aymaran groups also moved in a northwestern direction, with the Jaqaru language as its most tangible remainder (Cerron-Palomino 2000: 289-97).

According to Torero (2002: 127-131), Aymaran-speaking groups who were settled near Vilcashuaman and the valley of the Pampas river, at the border of the departments of Ayacucho and Apurimac, invaded the altiplano south of Lake Titicaca and most of the Bolivian highlands. In this final move of expansion they replaced almost all the local populations in that area, except for the Uru-Chipayan lake and river dwellers and a few pockets of Puquina speakers. This expansion must have taken place in the late middle ages, after the collapse of Tiahuanaco ( $\pm 1100 \mathrm{AD}$ ), but before the rise of the Inca Empire (after $1400 \mathrm{AD}$ ). In the mean time, Quechuan speaking groups obtained predominance in the southern highlands, where their language gradually replaced the local Aymaran (and possibly non-Aymaran) languages. This time, however, the variety of Quechuan that emerged as the dominant language was Quechua IIC, a locally developed variety of Quechuan now also known as Southern Peruvian Quechua (including Ayacucho Quechua, Cuzco Quechua, etc.). The process of quechuanization of the southern Peruvian highlands attained its completion between the 17th and the 19th centuries, when all the local languages disappeared, except for Aymara in a confined 
region to the north and the south of lake Titicaca (in the departments of Puno, Moquegua and Tacna) and Uru-Chipayan. The eastern and southern Bolivian highlands, still predominantly Aymara-speaking around 1600 (Bouysse-Cassagne 1975), also turned to Quechuan, probably as a result of the cosmopolitan attraction of the silver mining center of Potosi, one of the most populated cities of its time. It can be seen from the above that many of today's Quechuan-speaking areas only adopted varieties of Quechuan during the period of Spanish colonial rule. The

\section{camp_010.pod 590}

\section{7-10-12 14:21:11 -mu- mu}

590 Willem F.H. Adelaar

quechuanization of a large part of the Bolivian highlands, the completion of the quechuanization of southern Peru, the consolidation of Ecuadorian Quichua in the Ecuadorian highlands at the expense of the local native languages there, and the introduction of varieties of Quechuan in the Amazonian region of Ecuador and Peru and in the Argentinian northern lowlands (Santiago del Estero, Cordoba) are all largely post-conquest developments. Nevertheless, the exact chronology of these events is still a matter of debate, as in the case of the introduction of Quechuan in Ecuador and in Santiago del Estero (see, for instance, Hartmann 1979; Bravo 1993).

The Spanish administration was in principle favorable to the use of Quechua, which had been the administrative language of the Inca Empire during its final decades and which was considered to be a highly convenient tool for the evangelization of the Indians and the consolidation of Spanish power. During the 16th century, Quechua was mainly referred to as la lengua general del Ynga ('The general language of the Inca') or in shorter form la lengua general. Aymara, and initially Puquina as well, were also treated as general languages that were worth learning for the purpose of evangelization. Most other Andean languages, however, were neglected and ignored, and it is only thanks to coincidence and the personal motivation of individuals that grammars of Mochica (Carrera Daza [1644] 1939) and Cholon (de la Mata 1748; cf. Alexander-Bakkerus 2005, 2007) have been preserved. An attempt at standardization of Quechua and Aymara occurred following the Third Council of Lima (Tercer Concilio Limense) of 1583. The Doctrina Christiana and the Cathecism, written on the initiative of the clerical grammarians who participated in this meeting, contained a new unified version of the general language, 
intended to become the official standard of Quechua, as the language was henceforth called. This new Quechua standard was not meant to last. The more complicated and flowery Quechuan variety of Cuzco had a stronger basis because it was associated with past glory and the cultural expression of a nostalgic Inca elite. It turned out to be an ideal vehicle for an indigenous counter-culture that produced literary works, theater plays in particular, which were Spanish in form and content but indigenous in expression (cf. Mannheim 1991). From then on, Cuzco Quechua retained its privileged status, strongly defended by the Academia Mayor de la Lengua Quechua established in Cuzco (see above).

The demise of the major indigenous languages of the Andes began around 1770 , when the reformist rulers of the Bourbon dynasty started to impose a forced hispanicization, prohibiting the use of Quechua and other indigenous languages. This only became worse after the great rebellion of 1781 , headed by Tupac Amaru II, an indigenous nobleman from the Cuzco area. As a consequence of this rebellion, Spanish power was seriously threatened, and a harsh suppression of indigenous cultural and linguistic expressions followed. The longing for emancipation among the Indian population was crushed, and when the War of Independence

\section{camp_010.pod 591}

\section{7-10-12 14:21:11 -mu- mu}

Languages of the Middle Andes in areal-typological perspective 591

began, 30 years later, the Quechuan-speaking population and its aspirations hardly played any role in it. The oppression and marginalization of the Indian population of the new Andean nations Ecuador, Peru and Bolivia continued throughout the 19th century, and it was not before the second half of the 20th century that some sort of reappraisal of indigenous culture and languages occurred. In 1975, Quechua obtained the status of an official language in Peru, on a par with Spanish, a measure of which the immediate effect remained limited. Later on, comparable initiatives followed in the other Andean countries. Programs for the development of (intercultural) bilingual education, sponsored by foreign aid, especially in the 1980s and 1990s, contributed to awakening the interest for the indigenous languages in the Andes and to enhancing their prestige, both among the speakers themselves and among outsiders (cf. Howard 2007).

In the mean time, however, a massive process of language shift is underway that cannot easily be arrested. In large parts of the Peruvian countryside, Quechuan 
has been replaced with Spanish since the middle of the 20th century, a process that has radically reduced the size of the Quechuan-speaking area and has brought many historically interesting dialects and varieties to the verge of extinction (see Chirinos Rivera [2001] for a statistic analysis of the effects of this process). Selfesteem among the speakers of Andean languages is characteristically low, and it takes more than idealism to convince them not to abandon their ancestral languages after centuries of oppression and neglect. The situation in Ecuador and Bolivia, where the political situation favors the social and cultural mobilization of the Highland Indian population, is somewhat less critical.

\section{Issues of genetic relationships}

The genetic classification of the languages of the Middle Andean region continues to exhibit a general lack of progress, in spite of many past research efforts meant to improve the situation. This is not likely to change soon, due to a number of particular factors that differentiate the Middle Andean region from other linguistic areas. First, there is an unusual density of linguistic isolates and "shallow" families (such as Quechuan and Aymaran); secondly, many languages that may have constituted missing links have become extinct; and, thirdly, the state of documentation of all but two of these extinct languages is insufficient for use in serious comparative work. Linguistic connections of a genetic nature with areas outside the Middle Andean region are mainly limited to languages found in its periphery (Barbacoan, Jivaroan, Arawakan, Tupi-Guaranian, etc.).

A case of a possible external connection that does affect the heartland of the Middle Andes is the putative genetic link between Puquina and the Arawakan (Maipuran) family of the South American lowlands. It is based on noticeable similarities in the shape and use of personal pronominal markers, the shape of a nomicamp_

\section{0.pod 592}

\section{7-10-12 14:21:11 -mu- mu}

592 Willem F.H. Adelaar

nalizer, and the structure of nominal predicate constructions. Attested lexical similarities are too few to play a decisive role, but a systematic comparison of Puquina and Callahuaya lexicon with that of the different Arawakan languages remains a task for the future. As a matter of fact, all the other Middle Andean isolates and endemic families need to be compared with linguistic groupings external to the area, but so far the results have not been promising.11 
A major genetic issue that continues to bother Andeanists of all creeds is that of the alleged common origin of Quechuan and Aymaran. The issue harks back to the 17th century when a Jesuit scholar observed that the Quechua and Aymara languages shared so many elements and features that they must have sprung from some common origin "in the same way as Spanish and Italian both descended from Latin" (Cobo [1653], cited in Cerron-Palomino [2000: 298]). Truly, Quechuan and Aymaran show profound similarities on all linguistic levels (lexicon, phonology, morphosyntax and pragmatics), which can be highly specific and are not shared with other languages in the region. It is widely believed that specialists in Andean languages are split into two camps: those who favor a common origin for the two language groups and those who reject such a possibility but attribute the similarities to intensive borrowing and contact-induced structural remodelling. In reality, the positions have rarely been so outspoken.12 Few linguists reject the reality of borrowing and contact-induced structural parallelism, and when all the obvious loans are put aside, there is very little left that could be attributed to a remote common origin for Quechuan and Aymaran. Any formal similarities that cannot be easily attributed to borrowing generally fail to meet the requirement of regular sound correspondence needed for the establishment of convincing genetic links. If Quechuan and Aymaran should be genetically related at all, they would certainly not be closely related, and the moment of separation would probably be too early for such a relationship to be recovered with certainty (cf. above). Furthermore, it would be methodologically unsound not to involve other languages in the comparison when such early separation dates are at stake (even though in this case it is likely that possible related languages may have become extinct before they could be recorded). In what follows we shall first address the principal features that Quechuan and Aymaran have in common, as well as those in which they differ. Subsequently, we will look at external typological links that Quechuan and Aymaran have in common, as well as to possible typological features that involve only one of the two families. It should be remembered that both Quechuan and Aymaran are internally diversified families, and that few statements hold for all the modern varieties, particularly in the case of Quechuan. Many structural, phonological and lexical coincidences are in fact the result of secondary contact between geographically contiguous varieties, which may continue an age-old tradition of linguistic interaction. For instance, Cuzco Quechua and Aymara (in all its varieties) both have series of glottalized (ejective) and aspirated stops and affricates. This coincidence is not an 


\section{camp_010.pod 593}

\section{7-10-12 14:21:11 -mu- mu}

Languages of the Middle Andes in areal-typological perspective 593

indication that each of the hypothetical proto-languages of the two families had such series, which may have been limited to Aymaran.

As an example of secondary lexical borrowing, we may mention the case of the verb root hala- 'to run', 'to fly', which is used in the Quechua of Puno. This item is not attested in Quechuan varieties further to the north. It contains an intervocalic /, which is exceptional in southern Peruvian Quechua and which cannot be reconstructed for Quechuan as a whole. The root hala- is obviously a loan from Aymara.13 It cannot be assigned to the proto-lexicon of both language groups, even though it occurs in both.

Furthermore, some Quechuan varieties, viz. the Ecuadorian-Colombian branch and the Peruvian Amazonian varieties that were derived from it, have lost part of their complex morphology, which makes them look significantly different from both Aymaran and the Quechuan varieties of Peru and Bolivia, which are more conservative in this respect.

\section{The Quechuan-Aymaran contact model: An interpretation}

For all practical purposes, Proto-Quechuan and Proto-Aymaran are best treated as genetically unrelated languages. Even if they should share a common origin, which is not demonstrated, the issues of language contact and convergence are essential for the characterization and the understanding of the historical relationship between the two language groups. The absence of a demonstrable genetic relationship makes it uncertain if the predecessors of the two proto-languages were structurally as similar as the proto-languages themselves were. This state of affairs leaves room for a process of change and remodelling that could have occurred in an earlier stage of development of one of the two proto-languages. Thus, the predecessors of the proto-languages - or 'pre-proto-languages', as one may call them - would have co-existed in a situation of close contact during a considerable period of time. The archaic and more synthetic character of the Aymaran languages suggests that Pre-Proto-Aymaran may have provided the model, whereas Pre-Proto-Quechuan went through a process of restructuring that eventually resulted in Proto-Quechuan. ${ }_{14}$ Although the direction of the lexical borrowing is not always recoverable, there seems to have been a substantial amount of borrowing from Pre-Proto-Quechuan into Pre-Proto-Aymaran. One 
may speculate about a Pre-Proto-Aymaran-speaking population which became Pre-Proto-Quechuanized through conquest. Subsequently, the language of the conquerors may have been remodelled according to the language habits of the conquered population. Such an event could have occurred between $200 \mathrm{BC}$ and $200 \mathrm{AD}$, during the period of chaos and turmoil that followed the demise of the Chavin horizon and preceded the rise of the regional cultures of the Early Intermediate Period, such as Mochica in the north, Nazca in the south, and the NievCamp_

\section{0.pod 594}

\section{7-10-12 14:21:11 -mu- mu}

594 Willem F.H. Adelaar

eria and Cajamarquilla cultures in the valley of Lima on the central Peruvian coast (Torero 2002: 125).

\section{Quechuan and Aymaran: Structural similarities}

In the following enumeration of features common to both Quechuan and Aymaran we shall focus on features that can be reconstructed for both proto-languages. Particularities of varieties that are likely to be the result of ulterior innovations will not be discussed systematically. As we have noted before, the structural parallelism between Quechuan and Aymaran is striking. Insofar as the more conservative varieties of both families are concerned, it is often possible to find almost perfect matches between the meaningful elements that make up a phonological word or a sentence, including the way they are ordered and organized and a substantial amount of idiosyncratic detail. For a long time, both languages were considered prototypical for an agglutinative and suffixing "Andean" language type. Recent research, however, suggests that there are no other languages in the area that can be attributed to such an areal type in a straightforward way. The structural similarities between the two language families have been inventoried with much detail in Cerron-Palomino (1994) and, in a more definitive way, in its revised edition (Cerron-Palomino 2008). As a matter of fact, both Quechuan and Aymaran exhibit an agglutinative morphological structure, almost exclusively based on suffixation. Prefixes do not occur. ${ }_{15}$ Sequences of as many as eight suffixes are perfectly normal, and longer sequences may occur occasionally. Other strategies, such as reduplication, vowel modification, vowel suppression and distinctive stress assignment occur in both families but they may not be re-constructible for each of the proto-languages. Normally, there is a one-to-one relationship between meaning and form for each 
suffix. However, portmanteau suffixes, with distinct meaning components encoded within a single element or combination of elements, are not uncommon, particularly in the domain of personal reference, tense and mood.16 The order of the constituents in both Quechuan and Aymaran is predominantly SOV with a considerable tolerance for divergent constituent order in main sentences. In dependent clauses the order of the main constituents is strictly SOV, exceptions being highly infrequent.

Verbs and nouns are distinct classes each with its own morphology and its own set of affixes, although some affixes are formally similar and semantically related in both classes. Minor classes usually align with the nouns, so a division into verbs and non-verbs may be more appropriate than a division into verbs and nouns. Verbal roots and bases end in a vowel in both language groups and cannot occur by themselves without losing their verbal interpretation.17 They have to be followed by an inflectional affix that closes the verb form. (However, some of these affixes may take a zero form when closing a verbal base.)

\section{camp_010.pod 595}

\section{7-10-12 14:21:11 -mu- mu}

Languages of the Middle Andes in areal-typological perspective 595

The verbal and nominal classes are interrelated by explicit strategies of verbalization and nominalization. Nominalization plays an important role in Quechuan and Aymaran morphosyntax. Relative clauses and several types of adverbial clauses are based on nominalization.

Apart from natural semantic limitations, verbs are not specified for the transitive / intransitive distinction. Semantics permitting, verb roots can be interpreted both transitively and intransitively (compare English 'to turn', 'to break'). Valencyexpanding derivations, such as causative and applicative, apply to all verb roots without significant exceptions. In contrast to many other American Indian languages, Quechuan and Aymaran appear to be "indifferent" to the notion of transitivity. The syntactic alignment of Quechuan and Aymaran is strictly nominative-accusative. Subjects and nominal predicates are unmarked for case, but accusative case-marking is generally required on all lexically expressed objects (nouns, pronouns, nominalized verbs). ${ }_{18}$ There is one exception: In Quechuan, the lexically expressed object of a nominalized verb is not marked for accusative case when occurring before its head. A possible explanation is that originally a sequence of a 
nominalized verb preceded by its object may have been interpreted as a genitive construction.

In noun phrases, lexically expressed modifiers generally precede their heads. In noun phrases containing several modifiers the latter are strictly ordered according to the minor class to which they belong. As an exception to this rule, relative clauses headed by a nominalized verb may follow their antecedent in Central Peruvian Quechuan varieties. The alternative order, in which a clause headed by a nominalized verb precedes the noun to which it is linked, is also permitted, but in that case the relative clause character is less pronounced. In at least one Quechuan variety (that of Santiago del Estero in Argentina), an adjective follows the noun it modifies, possibly an areal feature.

When both the head and the modifier in a genitive construction are lexically expressed in Quechuan or Aymaran, they are both marked for possession. The modifier receives a genitive case marker, while the head noun is marked for the grammatical person of the possessor (triggering agreement when necessary). In some Quechuan varieties, there are genitive expressions in which only the head noun is marked. The opposite situation, a marked modifier followed by an unmarked head noun, is the normal practice in Ecuadorian Quechua, where the possession markers were lost.

The personal pronominal system of Quechuan and Aymaran distinguishes four basic categories identifying the grammatical person of a subject/actor and a direct or indirect object (with verbs), and a possessor (with nouns). These categories are: 1st person (speaker), 2nd (addressee), 3rd (none of either), and 4th (both speaker and addressee).19 Third person object is not overtly encoded. The 4th person category is generally interpreted as a first person plural inclusive (as opposed to the

\section{camp_010.pod 596}

\section{7-10-12 14:21:11 -mu- mu}

596 Willem F.H. Adelaar

plural form of 1 st person, which functions as a 1st person plural exclusive). However, it can also be used as a group identifier or a collective person marker (comparable to French on or Portuguese a gente), in which case the addressee need not always be included. In some Quechuan varieties (mainly those of Ecuador and Colombia), the system of personal pronominal marking has become eroded, and the grammatical person of an object and/or a possessor are no longer marked morphologically. 
Apart from possession, nouns can also be marked for number (plural) and for case. The case inventories of Quechuan and Aymaran are similar, although there is not full coincidence. Both language groups have an attributive affix that can be translated as 'having', 'provided with' (Quechua -yuq, Aymara -ni).

The existence of an elaborate system of verbal derivation or post-base morphology (Payne 1990) is one of the principal characteristics of both Quechuan and Aymaran. The meaning and use of these derivational affixes often coincide in detail, whereas formal coincidences are rare between the two language groups.20 The inventories of derivational affixes may differ considerably among the different varieties of Quechuan and Aymaran, although the Aymaran inventories tend to be richer. Due to the internal variation within each group, a reliable reconstruction of the derivational systems is difficult. Therefore, we cannot establish how much similarity there really was between the derivational systems of the proto-languages. Dependent clauses in Quechuan and Aymaran are headed by special adverbial verb forms (converbs) or by combinations of a nominalized verb with a particular case marker. Converbs in Quechuan are characterized by an elaborate system of switch-reference coding, whereas switch-reference in Aymaran is only moderately developed.

Both Quechuan and Aymaran have a set of affixes that can be attached to any constituent, regardless if it is nominal, verbal or adverbial. These elements may indicate such categories as topic, question, evidentiality, attitude, completion, inclusion, etc. They play an important role in the pragmatic organization of a discourse. Both Quechuan and Aymaran use evidential markers to indicate data source and attitude towards the veracity of a statement. Much societal importance is attached to a correct use of these evidentials.

As indicated above, relative clauses in Quechuan and Aymaran are normally constructed on the basis of nominalized verbs. More complex analytic constructions combining main verbs with interrogative and demonstrative pronouns are also available, but are not frequently used.

From a pragmatic point view, there is often an exact coincidence between specific constructions occurring in both language groups. For instance, an agentive nominalizer accompanying a verb of motion indicates the immediate purpose of that motion (Quechuan - $q+$ VERB; Aymaran -iri + VERB). A more remote purpose of any event is indicated by combining a nominalized verb indicating future action

\section{camp_010.pod 597}


07-10-12 14:21:11 -mu- mu

Languages of the Middle Andes in areal-typological perspective 597

(with suffix -na in most varieties of Quechuan, -nya in Aymara, -nušu in Jaqaru)

with a (nominal) marker of benefactive case (Quechuan -paq, Aymara -takı). Considering

the high degree of structural interference between Quechuan and Aymaran,

it may be risky to reconstruct these practices as features of the proto-languages.

\section{Quechuan and Aymaran: Structural differences}

The structural differences that have survived the extensive periods of intense contact

between the Quechuan and Aymaran language communities have received less

attention so far than the coincidences and tend to be overlooked. They may be significant

because they can provide an insight into the distinctive properties that may

have separated the two language groups originally. As an alternative possibility,

these properties may also be the result of independent secondary developments.

In Aymaran, the pronominal endings of finite verbs, which encode the grammatical

person of a subject and an object, as well as some distinctions of tense and

mood, are thoroughly merged and cannot easily be split into meaningful parts. By

contrast, in Quechuan a division into meaningful elements is possible in most

cases. The Quechuan subject-object combinations are transparent to a certain extent

and seem to be of a relatively recent coinage (cf. Adelaar 2009). It suggests

that Quechuan originally had a relatively simple system of verbal personal reference

marking, in which only a subject or agent could be specified, not an object

(with the possible exception of the combination of a 1st person subject acting upon

a 2nd person object).

In Aymaran, nominalized verbs can take the personal pronominal markers

proper to the nominal class, which are normally used to indicate the identity of a

possessor. These markers then refer to the subject/agent of the nominalized verb in

question. The object of a nominalized verb cannot be encoded morphologically. By

contrast, in Quechuan both a subject/agent and an object can be encoded in nominalized

verbs. These so-called "transitions" ${ }_{21}$ or complex pronominal markers are

inherited, as it were, from finite verbs and retain most of their verbal characteristics.

In other cases, however, a personal pronominal marker on a nominalized

verb can refer to a possessor. Since the possessive markers and the subject/agent

markers are formally the same, the criteria necessary to distinguish them are not

clear-cut.

Quechuan converbs feature an elaborate system of switch-reference marking, 
based on the distinction whether the subject of the converb is identical to or different from the subject of the main verb. When the subjects are not identical, both verbs have to be marked for grammatical person (subject and object when relevant). Quechuan varieties of the Ecuadorian branch have lost morphological person marking on converbs, but maintain a robust distinction of the two switch-refCamp

\section{0.pod 598}

\section{7-10-12 14:21:11 -mu- mu}

598 Willem F.H. Adelaar

erence options ('same subject' and 'different subjects'). In the Aymaran languages, switch-reference is either rudimentary or limited in its possibilities. Switch-reference is most clearly present in Jaqaru, where converb forms encoding a subject different from that of the main verb seem to reflect a sort of nominalization. As in the case of nominalized verbs, object encoding is impossible. It is not clear whether Aymaran switch-reference developed as a result of contact with varieties of Quechuan, or whether it constitutes an element inherited from Proto-Aymaran which is now in decline.

Quechuan has a copula verb ka- 'to be' and an existential verb $k a$ - 'to be present', 'to exist'. These verbs differ in their syntactic and pragmatic behavior but are otherwise formally identical. They are often treated as forms of a single verb with different pragmatic options. In the Aymaran languages, a morphological element $-k a$-occurs as an affix attached to the locative case marker $-n(a)$ with the meaning 'to be (at)'. There can be little doubt that the occurrence of a root or morpheme kain both language groups is a result of age-old contact. For the copular function, the Aymaran languages use a different morphological device. In Aymara, the final vowel of a nominal base (' $X$ ') is lengthened to produce a verb base ('to be $X$ ');22 in Jaqaru, a segmental element $-w$-is used for this purpose.

According to Cerron-Palomino (2000: 262-263, 2008: 160-161), both -ka- and vowel length are reflexes of a root $k a$ - that was identical in both Quechuan and Aymaran.

Of course, the assumed development of ${ }^{*} k a$ - to vowel length or $-w$ - is not entirely unproblematic. Nevertheless, the morphosyntactic parallelism between the morphological derivation in Aymaran and the syntactic construction in Quechuan is striking. In copular constructions the third person present form of the Quechua verb 'to be' is omitted whenever it is not marked for any other distinctions (tense, aspect, number, etc.). In Aymara, copular verbalization is omitted under 
exactly the same circumstances as the copula in Quechuan, and a non-verbalized noun is used instead. It suggests that Aymaran, like Quechuan, once also had a lexically independent copular verb, which became reduced to vowel lengthening or $-W$ -

Quechuan and Aymaran have sets of nominalizers that do not coincide entirely. Quechuan distinguishes an infinitive $-y$-and a future-oriented nominalization $-n(q) a$, which can also refer to the place of an event or an instrument. Aymaran languages have a special nominalizing affix referring to a place of event or an instrument $(-: w i)$, but Aymara merges the infinitive and future-oriented functions into a single affix - $n_{y} a$. Jaqaru nominalization differs from Aymara nominalization in several ways and is more like that of Quechuan, although not formally. A reconstruction of the nominalizers is problematic due to these different inventories.

Both Quechuan and Aymaran indicate case by means of affixes which are attached at the end of a noun phrase. The inventories do not coincide entirely. The Quechuan inventory includes case markers for, inter alia, genitive $-p(a)$, locative

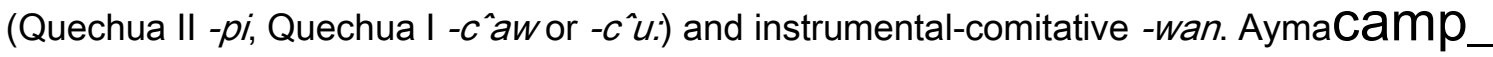

\section{0.pod 599}

\section{7-10-12 14:21:11 -mu- mu}

Languages of the Middle Andes in areal-typological perspective 599

ran has a single case marker $-n(a)$ for all these functions, except for a separate marker for the comitative function, which is -ws qa in Jaqaru and -mpi (or -nt/) in Aymara (Cerron-Palomino 2000: 209-211).23 The accusative case is marked in Quechuan with a suffix -(k)ta. Aymaran languages eliminate the final vowel of a nominal base for this purpose (in Aymara), or leave it mostly unchanged (in Jaqaru).

An accusative case marker *-ha, still occasionally used in Jaqaru, may be tentatively reconstructed for Proto-Aymaran (Cerron-Palomino 2000: 206-208). The reconstruction of case affix inventories is problematic for both language groups. Evidentials, also known as validators or data source markers in the literature on Andean languages, play an important role in Quechuan (cf. Floyd 1999; Faller 2002), where they take the form of affixes that operate at the sentence level (see above). Aymara has incorporated most of its evidentiality markers in its verbal system, thus increasing the number of verbal paradigms. Jaqaru seems to align more closely with Quechuan in this respect, suggesting that the Aymara developments may have been the result of innovation. The notion of mirativity (DeLancey 1997) 
plays an important role in the Quechuan verbal tense system and has even been copied into Andean Spanish.24 Its exact status in the Aymaran languages remains to be established.

The verbal derivational system or post-base morphology of Aymaran is more elaborate than that of Quechuan, in particular, in the domain of spatial affixes. Quechuan derivational affixes tend to be more multifunctional in comparison to Aymaran.

On the other hand, verbal derivation in both language groups also shows a great amount of functional coincidence, which may be due to the historical contact situation.

\section{Quechuan and Aymaran: Phonological coincidence}

Both the Quechuan and the Aymaran language families exhibit a relatively high degree of internal diversity in the domain of their sound inventories. By contrast, the phoneme systems that can be reconstructed for Proto-Quechuan and Proto-Aymaran are nearly identical with one notable exception: Proto-Aymaran made a distinction between glottalized (ejective), aspirated and plain stops and affricates, which is reflected in both its descendants.

In the Quechuan family, only a few varieties (though important in terms of numbers of speakers) that are likely to have an Aymaran substratum, maintain the distinction between glottalized, aspirated and plain consonants. For this sole reason the varieties in question, Cuzco and Puno Quechua, as well as Bolivian Quechua, are often incorrectly treated as a single homogeneous dialect. Aspirated stops or reflexes of aspirated stops are also found in the varieties of Quechuan of the Ecuadorian highlands. Their occurrence is generally attributed to a Cuzco Quechua adstratum, possibly favored by the phonological nature of the non-Quechuan

\section{camp_010.pod 600}

\section{7-10-12 14:21:11 -mu- mu}

600 Willem F.H. Adelaar

Table 1. Proto-Quechuan consonants, based on Adelaar with Muysken (2004: 196)

Table 2. Proto-Aymaran consonants, based on Cerron-Palomino (2000: 118) 25

substratum languages originally spoken there. Although certainly not all the problems surrounding the use of the glottalized and aspirated series in Quechuan have been satisfactorily solved, there seem to be insufficient reasons for reconstructing them in the proto-language. In varieties of Quechuan that have glottalized and aspirated consonants, these consonants are not normally used in affixes (only exceptionally), whereas this frequently occurs in Aymaran.26 Furthermore, in Quechuan 
the presence of glottalization and aspiration is limited to one instance per root, namely, on the first prevocalic stop or affricate, the two categories of consonants that can be subject to laryngeal modification. Nevertheless, in Aymara their use is not entirely free of restrictions either (Cerron-Palomino 2000: 173-175). It should be emphasized that the use of glottalization and aspiration in Quechuan varieties cannot be derived from an Aymaran model in a straightforward way. These phenomena acquired their own dynamism in Quechuan and spread through the lexicon in often unpredictable ways. Explanations that were brought forward, such as compensation for the loss of a phonological contrast, as in Quechuan roots originally

Labial Alveolar Palatal Retroflex Velar

Glottal

Uvular

Voiceless Obstruents $p \mathrm{t} \mathrm{c} \mathrm{c}^{\wedge} \mathrm{c}^{\wedge} \mathrm{kq}$

Fricatives $\mathrm{s} \mathrm{s}^{\mathrm{h}} \mathrm{h}$

Voiced Nasals $m \mathrm{n} \mathrm{n}_{\mathrm{y}}$

Laterals (I) ly

Rhotics $r\left(r^{2}\right)$

Glides w y

Labial Alveolar Palatal Retroflex Velar

Glottal

Uvular

Voiceless

obstruents

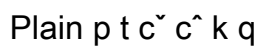

Aspirated phth $\mathrm{C}_{\mathrm{h}} \mathrm{C}_{\mathrm{h}} \mathrm{kh} \mathrm{qh}_{\mathrm{h}}$

Glottalized p' t' c"' c' ' k' q'

Voiceless

fricatives

$s s^{2} h$

Voiced Nasals $m \mathrm{n} n \mathrm{n}(\mathrm{\eta})$

Laterals I ly

Rhotics $r$

Glides w y

\section{camp_010.pod 601}

\section{7-10-12 14:21:11 -mu- mu}

Languages of the Middle Andes in areal-typological perspective 601

containing the retroflex affricate $c^{\wedge}$ (cf. Torero 1964: 464), and iconicity (Mannheim 
1991: 177-207) can account for some of the cases, but probably not for all. Apart from the issue of glottalized and aspirated stops and affricates, the reconstructed phoneme systems of Quechuan and Aymaran are remarkably the same.

Both proto-languages made a distinction between velar and uvular stops $(k, q)$, and between alveopalatal and retroflex affricates $\left(c^{v}, c\right)$. Both proto-languages had the palatal resonants $l_{y}$ and $n_{y}$, as well as the alveolar and alveopalatal sibilants $s$ and $s$. Some differences in the phoneme inventories of the two proto-languages are worth noting: the near absence of a plain, non-palatal lateral /in Quechuan and the absence of word-initial $r$ in Aymaran. In loan words, Quechuan word-initial $r$ corresponds to /in Aymara and to $n$ in Jaqaru, apart from recent loans that no longer reflect this correspondence. Furthermore, Proto-Aymaran had an intervocalic velar nasal $\eta$ with a limited contrastive function, which did not occur in Proto-Quechuan (cf. Adelaar 1996).27

Most important of all, the vowel system of the two proto-languages was trivocalic, consisting of two high vowels $i$ and $u$, and one low vowel $a$. In most modern descendant varieties, both high vowels are automatically lowered to a mid position ([e], [o]) when adjacent to a uvular consonant, and this was probably also the case in the proto-languages. Since the European invasion, the position of the mid vowels has been reinforced by borrowings from Spanish, a few neologisms and an occasional spread of the lowering effect to other environments, hence modern Quechuan varieties are frequently analyzed as having a five-vowel inventory. However, the tri-vocalic character of the original Quechuan and Aymaran vowel systems is not open to doubt.

The main difference between the Quechuan and Aymaran proto-languages did not lie in the composition of their phoneme inventories, but in their highly distinctive phonotactics and morphophonology. Whereas neither of the two proto-languages allowed tautosyllabic consonant clusters in the underlying form of morphemes (roots and affixes), the Aymaran languages have inherited from their common ancestor a set of suppression rules that apply to vowels preceding specific suffixes. These suppression rules are, so to say, part of the formal description of the suffixes that trigger them, and they appear to be phonologically unmotivated. They are responsible for the impressive clusters of up to six consonants that occur at morpheme boundaries in the Aymaran languages but are unknown in Quechuan. In both Quechuan and Aymaran, verb roots have to end in a vowel and are obligatorily followed by suffixes. In the Aymaran languages, nouns and affixes liable 
to appear in word-final position have to end in a vowel as well (at least underlyingly). By contrast, Quechuan does allow nouns, particles and affixes with a final consonant. Affixes can also consist in a single, potentially word-final consonant. Understandably, this state of affairs, which may hark back to the proto-languages, is especially helpful for the identification of loan words from Quechuan and other languages into Aymaran, because they take an added vowel when consonant-final

\section{camp_010.pod 602}

\section{7-10-12 14:21:11 -mu- mu}

602 Willem F.H. Adelaar

forms in the donor language are involved. Finally, Proto-Aymaran seems to have had a preference for morphemes consisting of open syllables and a more restricted inventory of morpheme-internal consonant clusters than Proto-Quechuan had.

\section{Lexical overlapping between Quechuan and Aymaran}

The circumstance that has probably contributed most to the idea that Quechuan and Aymaran are genetically related is the amount of lexicon they share. In addition to the occasional borrowings that occurred between the different branches of the two language groups, Quechuan and Aymaran exhibit an overlap of about 20 percent in the reconstructed lexicon of each family. The shared items include words that can be considered to belong to the basic vocabulary, such as nina 'fire' and warmi 'woman', and a substantial number of very elementary verbs such as apa- 'to carry' and muna- 'to want'. Furthermore, the reconstructed shared items are not only similar in form across the two language groups, they are identical in most cases; e.g., Quechuan quc`a, quc`a< Proto-Quechuan *quc`a, Aymara quta, Jaqaru quc $a<$ Proto-Aymaran 'quc $a$ 'lake'. By contrast, the remainder of the reconstructed lexicon does not show systematic correspondences across the two protolanguages, if there are similarities at all. 28 This state of affairs leaves practically no room for any other conclusion than that of intensive borrowing at the level of the proto-languages. A genetic relationship reflecting a still older common proto-language would carry signs of divergence visible through sets of cognates differing in a systematic and predictable way. Yet, such cognate sets have not been found. For some cognate pairs the source language of the borrowing can easily be identified, for instance, when the Aymaran item contains an added root vowel. In Quechuan pac âk, pac àk (from Proto-Quechuan "pac`ak), and Aymara pataka, Jaqaru pac'aka (from Proto-Aymaran "pac'aka) 'hundred',29 the Quechuan source can be determined from the presence of an added vowel in the Aymaran form. In 
many other cases, however, it is no longer possible to establish the direction of the borrowing. The answer to the question why so many vocabulary items were borrowed at such an early stage of interaction between the two languages must be sought in an analysis of the social and historical circumstances under which that interaction occurred.

\section{External distribution of typological features found in Quechuan and Aymaran: Phonological features}

As we have seen, the Quechuan and Aymaran language families are hard to classify, both in relation to each other and as far as external connections are concerned. In what follows, we will explore languages of neighboring areas for similarities to

\section{camp_010.pod 603}

\section{7-10-12 14:21:11 -mu- mu}

Languages of the Middle Andes in areal-typological perspective 603 the main typological features found in these two language groups, and we will try and see if meaningful areal distribution patterns emerge. 30 Where necessary, a broader New World picture will be provided. Because of their straightforwardness, phonological features will be examined first.

Vowel systems with only three basic vowels $(a, i, u)$ - disregarding length, nasality, and other secondary modifications of these basic vowels - are not common in South America. In the Andean region, systems of five or six vowels predominate. In the eastern lowlands of South America vowel systems that are even more complex are found. However, tri-vocalic systems occur in a few Arawakan languages spoken in regions that are adjacent to Quechuan-speaking or formerly Quechuanspeaking areas, namely Amuesha (with the vowels $a, e, o$ ) and the Upper Perene variety of Asheninka (Payne 1989). Since most Arawakan languages of lowland Peru tend to have more than three basic vowels, there can hardly be any doubt that we are dealing here with a case of areal diffusion, in which specific Arawakan languages adjusted to the pattern of Quechuan or a typologically similar extinct language. The extinct Culli language of northern Peru is too poorly documented to provide answers to any specific questions about its phoneme inventory, but the distribution of mid vowels $e, o$ in place names suggests that their occurrence was conditioned by the adjacency of what may have been a uvular stop ( $q$, see below) or a rhotic $(r) .31$ This conditioning may be tentatively ascribed to the sort of vowel variation characteristic of three-vowel systems. The Jivaroan, Zaparoan and Cahuapanan languages, adjacent to the northern part of the Middle Andes 
also have relatively limited vowel systems, consisting of the vowels $a$, e/i, o/uaccompanied by a central vowel. The nearest incontestable examples of three-vowel systems in the Americas are found in Nicaragua (Miskito, Rama) and in the southern tip of South America (Tehuelche, Teushen; possibly Kawesqar). 32 Contrastive vowel length is not a reconstructible feature of the Quechuan and Aymaran language groups, but it occurs in many of their present-day varieties. Contrastive vowel length is relatively rare in the languages of South America. Apart from Quechuan and Aymaran, it occurs in the Uru-Chipayan languages and in Callahuaya. The data for Puquina are too poor to decide on, but the occasional use of doubled vowels in the orthography of Ore's Puquina texts (Ore 1607) is a possible indication. Vowel length in Middle Andean languages usually has its origin in the loss of an intervocalic consonant ( $V C V>V$ :) or the modification of a coda $(V C>V$ : $)$. Contrastive vowel length was almost certainly also present in Mochica, and possibly in Atacameno. Among the Arawakan languages adjacent to Quechuan, Amuesha, Asheninka and Chamicuro have distinctive vowel length (Payne 1991). Other examples of contrastive vowel length are found in Colombia (Chocoan, Chimila, Paez, Guajiro) and in the far south (Tehuelche, Yahgan).33 Vowel length is also found in languages of the Gran Chaco (e.g. Ayoreo).

The distinction between velar and uvularstops is deeply anchored in both the Quechuan and the Aymaran language families. From a South American point of

\section{camp_010.pod 604}

\section{7-10-12 14:21:11 -mu- mu}

604 Willem F.H. Adelaar

view, the distribution of uvulars and the velar/uvular contrast are geographically limited. Uvulars are not found in the eastern lowlands of South America, nor in the north of the Andean region. To the immediate north of the Quechuan-speaking region, the extinct Culli language may have had a contrast between uvular and velar stops. This is suggested by a diacritic mark in the Culli version of the comparative wordlists collected by Martinez Companon ([1782-1790] 1985). It is found on the symbols $<\mathrm{c}>$ and $\langle\mathrm{g}>$ or on mid vowels adjacent to these symbols, e.g. <collapu $>$ 'to die', <ogoll> 'child'. The presence of this diacritic appears to be related to the use of mid vowels, suggesting that the Quechuan and Aymaran rule lowering high vowels to mid position in the vicinity of uvulars applied to Culli as well. The interpretation of $\left\langle c^{2}\right\rangle$ as a uvular stop is reinforced by the fact that it also occurs in the 
neighborhood of a low vowel, where the high-mid distinction does not play a role, e.g. in <c au > 'rain' (also attested in the present-day toponym Cauday, presumably translatable as 'mountain of rain').

Family names, such as $O c c$, in the area of Chachapoyas, suggest that the extinct Chacha language may have known uvular consonants, considering that in Andean colonial sources the sequence $c c$ was normally used to write uvular stops. Torero (2002: 164-201) posits uvular stops and nasals for the extinct Cholon language on the basis of two verb roots, but we have not been able to find corroborating evidence for such an interpretation of the data in de la Mata's grammar, the principal source for the Cholon language (Alexander-Bakkerus 2005, 2007).34 Towards the south, the presence of contrastive uvulars is more general. They are found in the Uru-Chipayan languages and in Callahuaya.35 The occurrence of uvulars in the extinct Puquina and Atacameno languages is likely. The Puquina vocabulary comprises several words that have cognates with uvular consonants in Callahuaya. The orthography $<$ ck $>$, which is used for back consonants in the main source for Atacameno (Vaisse et al. 1896), suggests that this language had uvulars but no velars, a typologically unusual situation. The spelling $<c k>$ is frequently used to represent a voiceless uvular stop in Argentinean orthographic practice, and there is no reason to assume that it had a different function in this case. In the Leco language, there is a fricative phoneme that has a non-contrastive uvular pronunciation in some environments (van de Kerke 2009).

The high incidence of uvular consonants (stops and fricatives) in substratum words of the Argentinean Quechuan variety of Santiago del Estero suggests that the underlying Diaguita and Tonocote languages also had uvulars. In addition, uvulars are found in Vilela (and possibly in the extinct Lule language, to which it is related) and in the Matacoan and Guaicuruan language families of the Gran Chaco region. The evidence for uvulars in the Huarpean languages is thin (cf. Torero 2002: 504-505). Further to the south, the Chon languages of Patagonia (Tehuelche, Ona and Gununa Yajich) had uvulars, as well as Kawesqar in the archipelago of southern Chile. For Kawesqar, the available descriptions (e.g. Aguilera 1978; Clairis 1987) suggest, as for Atacameno, that the uvular stop lacks a velar counterpart.

\section{camp_010.pod 605}

\section{7-10-12 14:21:11 -mu- mu}

Languages of the Middle Andes in areal-typological perspective 605 
In most of the Matacoan languages, the difference between velar and uvular consonants is not contrastive either (Campbell, personal communication).

Outside South America, uvular stops are found in the Mayan and Totonacan languages (in Mesoamerica) and in many languages of the North American Pacific coast and its neighboring interior. It is not impossible that this highly characteristic distribution of the velar/uvular contrast in the Americas may turn out to be significant one day. For Quechuan and Aymaran, the immediate conclusion is that of a possible areal link with the languages that are located to the south and southeast of the Middle Andean region.

Interestingly, the distribution of glottalized obstruents throughout the Americas is very similar to that of the uvulars. Glottalized stops and affricates are found in a large area to the southeast of the Quechua-Aymaran highland, where this phenomenon also extends to Uru-Chipayan, Callahuaya (possibly to Puquina as well) and to Atacameno. Ronald Olson and Liliane Porterie (cited in Torero 2002: 471-472) suggested that glottalized consonants in Uru-Chipayan may represent a case of diffusion from Aymaran because of their low frequency. Further to the southeast, glottalized consonants are widely found in the Matacoan languages of the Gran Chaco, in the Chonan languages of Patagonia (Tehuelche, Ona and Gununa Yajich) and in Kawesqar. In contrast to the uvulars, glottalized consonants are not entirely absent from the Amazonian region. They are found in the isolates Itonama and Leco (Bolivia), in Jebero (Cahuapanan, Peru), 36 and in Piaroa (Salivan, Venezuela), apparently a set of unrelated cases (for more cases see Campbell typology, this volume).

Looking north, there are no cases of glottalized consonants until one reaches Central America, where they are found in the Mayan languages, in Xinkan (Guatemala), in Lencan (El Salvador and Honduras), in Jicaquean (Honduras), and in Tequistlatecan (also called Chontal of Oaxaca, Mexico). They are also found in Mexican languages further north, such as Tepehua (Totonacan), Mazahua and Pame (Otomanguean).

Glottalization is again frequent along the North American Pacific coast and in its interior. The near coincidence of areas using uvulars and glottalized consonants in the Americas is a significant fact that deserves further investigation.

The distribution of aspirated obstruents does not coincide with the use of glottalized consonants anywhere in South America except in the Middle Andes. Apart from Aymaran and a number of varieties of Quechuan, aspirated consonants are 
found in Callahuaya and in Uru-Chipayan, possibly also in Puquina and in Atacameno. The doubt concerning the aspiration in Atacameno has to do with the question whether it has to be interpreted as a feature of an adjacent consonant or as a feature of a vowel. In the far south of South America, aspirated consonants have been reported for Kawesqar. In addition, aspirated consonants are occasionally found in the Amazonian region, in Arawan languages, Arawakan languages (including Proto-Arawakan [Payne 1991] and some of its descendant languages),

\section{camp_010.pod 606}

\section{7-10-12 14:21:11 -mu- mu}

606 Willem F.H. Adelaar

Bora, Leco, Moseten, Yanomaman and Yaruro, and in the area north of the Middle Andes, in Chocoan, Cofan, Paez, and Tinigua). In Meso-America aspirated consonants appear in Purepecha (Tarascan). Aspirated consonants are also found in a number of North American Indian languages.

In South America, sound systems that combine a plain, a glottalized and an aspirated obstruent series for different points of articulation appear to be restricted to the Middle Andes, where, apart from Quechuan and Aymaran, they are found in Uru-Chipayan, in Callahuaya, in Leco, and possibly also in Puquina and Atacameno. In the southern tip of South America, Kawesqar, has such a system (Clairis 1987: 361-378). For the nearest example of such a system outside the Andes one has to travel as far north as California. The Pomoan languages, for instance, have these three series as well as a distinction between velar and uvular consonants. Retroflex affricates in contrast with alveopalatal affricates can be reconstructed for Proto-Quechuan and for Proto-Aymaran. Although retroflex affricates are only preserved in the Quechuan varieties of Cajamarca, Chachapoyas and Pacaraos, in part of the Quechua I varieties (particularly the southern half), and in Jaqaru (Aymaran), their extension must have been more general in the past. The only other Middle Andean language that has retroflex affricates is Chipaya. Furthermore, Amuesha and Chamicuro, two Arawakan languages that are located not far from Central Peruvian Quechuan, have retroflex affricates as well. It may be a contactinduced phenomenon, but it has to be considered that the retroflex affricate is also found in Amuesha and Chamicuro words that are not of Quechuan origin (e.g. Amuesha $c^{\wedge} 0: p$ 'corn').

To the north of the Middle Andean region, the retroflex affricate is found in 
southern Colombia, in the Kamsa and Guambiano languages, and, south of the Middle Andean region, in Mapuche, Gununa Yajich and, according to Poblete and Salas (1999), also in Yahgan. However, in Mapuche the retroflex affricate varies with a retroflex stop, and the earliest historical source of importance (Valdivia [1606] 1887) suggests that the stop may have been the original form. In a more distant location, retroflex affricates are found in Mesoamerica, in Popolocan (VeermanLeichsenring 1991) and in several Mayan languages of the Mamean and Q'anjobalan subgroups (see Campbell typology, this volume). The distribution pattern for the retroflex stop is too dispersed to make any strong areal claims, except for the nuclear area of the Middle Andes itself. Note, however, that it is difficult to recognize retroflex consonants in extinct languages that have been recorded in pre-modern orthographies.

Another remarkable speech sound is a contrastive velar nasal, which can be reconstructed for Proto-Aymaran. It is found today in Jaqaru and in some Aymara dialects in the border area of Bolivia, Chile and Peru. Its distribution suggests a genesis not much older than the stage of the Aymaran proto-language. Contrastive velar nasals were also found in Cholon and in Mochica, and they still exist in MaCamp_

\section{0.pod 607}

\section{7-10-12 14:21:11 -mu- mu}

Languages of the Middle Andes in areal-typological perspective 607

puche. The velar nasal is very common in languages of the tropical lowlands of South America (e.g. in Tupian and Jean languages).

A non-palatal lateral gap, that is, the occurrence of a palatal lateral not matched by a non-palatal counterpart is shared by Proto-Quechuan and Amuesha. Like the three-vowel system and the occurrence of a retroflex affricate, this is yet another example of the convergence that links Arawakan and Quechuan in central Peru (cf. Wise 1976; Adelaar 2006). This convergence may not be particularly old, but it is certainly significant from the point of view of a hypothesis of linguistic diffusion.

\section{External distribution of typological features found in Quechua and Aymaran: Morphosyntactic features}

Probably the most striking common feature of Quechuan and Aymaran morphosyntax is its strictly suffixing and regular agg/utinative structure. This structure, which combines a well developed nominal morphology with a highly elaborate derivational and inflectional verbal post-base morphology, has often been presented as prototypical for the Andean region (e.g. in Tovar 1961: 194-199). As a 
matter of fact, few other languages in the Americas share this type of structure.

From a typological point of view, Quechuan and Aymaran are quite exceptional, and in this respect they resemble Old World languages such as Turkic, rather than the surrounding languages. One of the few language groups in South America that resemble Quechuan and Aymaran in its morphosyntactic structure is the Jivaroan language family in Ecuador and northern Peru. In Mesoamerica, Purepecha (Tarascan), and possibly Cuitlatec, both linguistic isolates, have a similar structure.

Although the specific language type of Quechuan and Aymaran with its highly complex post-base morphology and well developed nominal morphology is not common in the Americas, there are quite a few other languages in the Andean region and in the adjacent eastern lowlands that rely mainly on suffixation for their flectional and derivational morphology. Apart from Jivaroan, these are, for instance, the Panoan languages, the Barbacoan languages, the Cahuapanan languages, the Chocoan languages, part of the Chibchan languages (Cuna, Chimila, Tunebo), the Tucanoan languages, Paez, Esmeraldeno, Mochica, Puquina, Callahuaya, Uru-Chipayan, Mosetenan, Lule,37 Huarpean and Mapuche. A predominantly suffixing structure may be seen as an areal trait of the languages of the Andean region. Nevertheless, the widespread American Indian language type characterized by a mix of prefixes and suffixes, in which the former include (part of) the personal pronominal markers, is also represented in the Andes with Atacameno, Cholon and the Chibchan languages Muisca, Ika, Kogi and Damana.

A difficulty with the delimitation of exclusively suffixing languages vis-a-vis languages that present a mixed structure of prefixes and suffixes is the presence in

\section{camp_010.pod 608}

\section{7-10-12 14:21:11 -mu- mu}

608 Willem F.H. Adelaar

some of the former of clitic-like possessive modifiers that precede nouns (compare mi 'my', tu 'your' and su 'his/her/their' in Spanish). These possessive modifiers often occupy the place of prefixes in related languages. So it is possible that we have to do with degrammaticalized prefixes. 38 Andean languages exemplifying this type of modifiers are Chimila (Chibchan), Puquina and Mapuche. From a strictly morphological point of view, these languages rely mainly on suffixes, but these are supplemented by the use of pre-clitic possessive modifiers. Because of its elaborate and highly regular post-base morphology, Mapuche has often been treated as 
yet another example of the Andean language type, comparable to Quechuan and Aymaran, but it differs from them precisely by its use of pre-clitic possessive modifiers and by its rudimentary nominal morphology. The Puquina language exhibits an ambiguous situation in that it sometimes undergoes sandhi when possessive modifiers (and demonstrative modifiers, for that matter) are attached directly to the root, but they behave as separate words when an adjective intervenes (e.g. pakas 'world', po=wakas 'your world', but po atot huc'a 'your great sin'). 39 As we have seen, Puquina may be remotely related to the Arawakan languages, where the status of pre-posed personal pronominal markers can also be ambiguous (see Danielsen [2008] for an interpretation of such markers as pre-clitics in Baure). It may very well be that languages such as Mapuche and Puquina developed towards a $100 \%$ suffixing language type by losing their prefixes under areal pressure or by upgrading them to the level of clitics or free forms.

Personal pronominal markers involving more than one speech act participant are a frequent characteristic of New World languages. Most languages use prefixes or, more often, combinations of prefixes and suffixes for this purpose, so that the roles of actor/subject and (in)direct object can be kept apart formally. An outstanding feature of the suffixing languages Quechuan and Aymaran is that these categories are necessarily expressed in the suffix part of the verb, where they are subject to a great deal of fusion, both with each other and with the surrounding tense and mood markers. Aymaran exhibits the highest degree of fusion (laying a greater burden on a learner's memory) because the endings can no longer be straightforwardly split into recognizable components. Languages that also have a suffixal system of partly fused personal pronominal marking with combined subject/actor and object coding, apart from Quechuan and Aymaran, are: Mapuche, Puquina, Moseten, Jivaroan, Yaruro (in the state of Apure, Venezuela, cf. Mosonyi [1966]), and the Kwaza language of Rondonia (van der Voort 2004). As a mixed language, Callahuaya behaves like Quechuan.

A characteristic by-product of the above-mentioned complex pronominal endings is the presence of inverse markers intended to recycle personal reference endings in different functions. Such a mechanism is found in Quechuan, Puquina and Mapuche. It has the function of assigning an object role to endings that otherwise refer to a subject or actor (cf. Adelaar 2009). Examples are $-s^{\llcorner} u$-in (Central Peruvian) Quechuan maqa-s úu-nki 'he/she beats you', compare maqa-nki 'you beat camp_010.pod 609 
07-10-12 14:21:11 -mu- mu

Languages of the Middle Andes in areal-typological perspective 609

(him/her)'; -s- in Puquina too-s-pi 'he/she brings you', compare too-pi 'you bring (him/her)'; and -e-in Mapuche leli-e-n 'you looked at me', leli-e-n-ew 'he/she looked at me', compare leli-n 'I looked (at him/her)', leli-fi-n 'I looked at him/her'. Inverse markers have the advantage that the different subject-object combinations can be expressed with a minimal amount of extra affixes. They are often matched by a hierarchy assigned to the grammatical persons, as in Mapuche, where that hierarchy is $1>2>3 a>3 b$ (' $3 b$ ' referring to a 3rd person external to the speech event). Mochica also has a hierarchy, which dictates the use of a passive whenever a patient or object occupies a higher place in the hierarchy than the actor (Torero 2002: 351-357).40 An inverse-direct distinction and a hierarchy of grammatical persons are also found in Movima (Haude 2006).

A feature that drew the attention of Wilhelm von Humboldt in the early 19th century is the relative location of subject and tense coding in the verb (Ringmacher and Tintemann, forthcoming). Quechuan and Aymaran coincide with Latin and other Indo-European languages by expressing the grammatical person of the subject at the right-side periphery of the verb form. Personal pronominal markers can be separated from a verbal base by tense and mood markers if any are present. Humboldt considered this an indication of the higher degree of development of the major Andean languages as compared to Amazonian languages that integrate personal pronominal marking with the verbal base, leaving the expression of tense to peripheral clitics or adverbs. Such a hierarchical categorization of languages has rightly be abandoned, but it is interesting that many subject-marking suffixing languages adhere to the Quechuan-Aymaran model: Puquina, Mapuche, Jivaroan, Tucanoan and, to a certain extent, also Mochica.41 Contrarily to what may be expected, the elaborate post-base morpholog $y_{42}$ of Quechuan and Aymaran is not confined to languages representing the agglutinative suffixing type, such as Mapuche and Jebero (Cahuapanan) (Bendor-Samuel 1961).43 The post-base morphology of Amuesha, Asheninka and other pre-Andine Arawakan languages is just as elaborate as that of Quechuan and Aymaran, although these languages combine prefixing and suffixing morphology like the majority of the Arawakan languages do. Assuming that an elaborate verbal post-base morphology is not a characteristic of the Arawakan family as a whole, we may be dealing here with a strong case of convergence affecting highland and eastern 
slopes languages of Central Peru.44 This is in line with the phonological similarities between Amuesha and Quechuan that we have noted earlier. For many South American languages, it may not be possible yet to establish the full extent of the complexity of their post-base morphology due to incomplete descriptions. For extinct languages it may remain impossible because not all traditional grammarians accorded equal attention to this complex and relatively impenetrable part of the grammar. Another difficulty is how to compare the degree of grammaticalization of the affixes involved in post-base morphology. Languages such as Quechuan, Aymaran, Amuesha and Mapuche have a set of closing affixes that clearly mark the

\section{camp_010.pod 610}

\section{7-10-12 14:21:11 -mu- mu}

\section{Willem F.H. Adelaar}

boundary of a word, locking derivational affixes inside. Internally, the affixes are governed by strict rules of order and co-occurrence restrictions. Other languages with rich suffixation, for instance Tupi-Guaranian, feature a looser structure of post-base morphemes, some of which can be interpreted as clitics.

The marking of switch-reference in dependent verbs is a highly characteristic feature of the Quechuan language group. It has a clear function in discourse, where it is used to summarize the information of a previous sentence and to keep track of participants in a speech event, thus avoiding explicit repetitions of the subject. In conservative varieties of Quechuan, switch-reference is marked on dependent verbs (converbs) that refer to events previous or simultaneous to the main verb. When the subjects of the dependent verb and the main verb are different, the full set of subject-object combinations is in use. 45 Ecuadorian Quechuan no longer has personal pronominal marking on the dependent verb, but the distinction between the same-subject and different-subjects categories is maintained. At least one sub-variety of Ecuadorean Quechuan (Imbabura Quechua) has expanded its switch-reference system by adding a distinction that applies to the future and is used in purpose clauses. Switch-reference also occupies an important place in Chipaya, in the Barbacoan languages (Tsafiki, Cha'palaachi), in Jivaroan, in Tucanoan, and in the Panoan languages, where it attains a high degree of complexity due to the ergative structure of these languages. Within the Aymaran language family, Jaqaru has a fairly developed switch-reference system with a different-subjects category that only encodes subjects (not objects). In Aymara, some dialects have a vestigial different- 
subjects form for the third person. It is not clear if switch-reference categories were lost in Aymara or that they simply failed to develop. Switch-reference is clearly an areal feature of western South America extending from the Ecuadorian coast to the Bolivian altiplano. It is also widely found in native languages of North America, but it has not been attested in the intervening regions. Mapuche has a conditional dependent verb form with personal pronominal markers for subject and subject-object combinations, but it is not part of a switch-reference system. Nominalization plays a central role in Quechuan and Aymaran. The most common type of relative clauses is based on the presence of a nominalized verb. Complement clauses are formed by combining a nominalized verbs with a case marker.

The addition of case markers to verb forms that have not previously been nominalized is not allowed. A neighboring language, Cholon, has no such restriction and can attach case markers both to nominalized verbs and to finite verbs. ${ }_{46}$ Nominalizations play an equally important role in the Barbacoan languages and also in Mapuche, which lacks case markers but has a relatively large inventory of nominalizing strategies. It may not be possible to give a full account of the role of nominalizations in the languages of western South America, especially the extinct languages, for lack of relevant data.

As we have seen, the personal pronominal system of Quechuan and Aymaran is based on a four-way distinction represented by four grammatical person catCamp_

\section{0.pod 611}

\section{7-10-12 14:21:11 -mu- mu}

Languages of the Middle Andes in areal-typological perspective 611

egories. This system, in which the category of number (plurality) only plays an accessory role, is most clearly visible in Aymaran, where each of the four categories receives an independent formal expression, for instance, in the Jaqaru possessive markers -na 'my', 'our (exclusive)'; -ma 'your'; -pha 'his/her/its/their'; -sa 'our (inclusive)'. In its conservative varieties, Quechuan has the same system. However, no clear underived morpheme can be reconstructed for the first person plural inclusive (often referred to as 4th person), so that the Quechuan system appears to be the result of a process of restructuring based on an Aymaran model. On the other hand, many American Indian languages and language families have personal pronoun systems that include a separate expression for the 1st person plural, whereas 2nd and 3rd person plural are indicated by derived expressions. Such systems seem 
to reflect four-person systems of the Aymaran type. Many of them subsequently developed a secondarily expressed distinction between an inclusive and an exclusive 1st person plural. Such an Aymaran-style four-person system is reflected in several Andean languages and language families, including Mapuche, Puquina, Uru-Chipayan, Cholon, Guahiboan and Chibchan (e,g. in Kogi). Furthermore, it is also widely found outside the Andean region, for instance, in Cariban, Jean, Guaycuruan, Matacoan, some Mayan languages, and Uto-Aztecan, suggesting that it harks back to the oldest layers of New World linguistic history. Interestingly, the Aymaran languages seem to be among the few language groups that preserve this system in its unmodified form. (For a similar case in Matacoan, see Campbell typology, this volume.)

The case suffixes and postpositions in Quechuan and Aymaran are not unique in that such markers are widely used within the South American languages, particularly in the languages of the Andean region. Case markers are easily borrowed as can be seen in Amuesha, which has borrowed the Quechuan benefactive marker -paq, and in (Barbacoan) Awa Pit, which shares the accusative and genitive case markers with Quechuan. Aguaruna (Jivaroan) has an accusative-genitive marker -na (Overall 2008) similar to the Aymaran locative-genitive marker - $n(a)$. The stacking of case markers, either genitive or instrumental with another case, is frequent in Quechuan (e.g. runa-pa-ta 'that of the person (accusative)' with genitive marker - pa and accusative marker -ta). Such combinations (with genitive) are even more usual in Mochica. In Quechuan, several monomorphemic case markers, such as (Quechua II) ablative -manta, appear to have a composite origin (allative -man followed by accusative -ta). Complex case markers are also found in Cholon (Alexander-Bakkerus 2005: 143-151) and in Uru-Chipayan (Cerron-Palomino 2006: 122-130).

One aspect that distinguishes Quechuan and Aymaran from most other languages in South America is the use of an explicit accusative case marker on the direct object. Constenla Umana (1991) recognizes an accusative-marking typological area in Southern Colombia (in the Barbacoan languages Awa Pit and Guambiano, and in Paez), which includes Quechuan. As we saw, accusative case camp_010.pod 612

07-10-12 14:21:11 -mu- mu

612 Willem F.H. Adelaar 
markers are also found in the Jivaroan languages. Apart from these, only Puquina has a possible accusative marker, which is not consistently used in the only source for that language (Ore 1607). Most other languages in South America leave the object unmarked. 47

Quechuan and Aymaran are dependent marking languages. Possession is indicated by a genitive case marker on the noun or pronoun referring to the possessor. At the same time, the grammatical person of the possessor must be encoded on the possessed noun. So, possessive phrases in Quechuan and Aymaran are doubly marked, provided that both constituents of the construction are overt; e.g. Ayacucho Quechua runa-pa wasi- $n$ [person-GEN house-3Poss] 'a person's house'.48 The same system is found in Jivaroan (Overall 2008). Barbacoan Awa Pit and Mochica have dependent marked genitives, but no doubly marked constructions. Most other languages in the Andes and their surroundings lack dependently marked genitives. They are either head-marked (Mapuche, for instance), or the genitive is indicated by juxtaposition. Muisca (Chibchan) and the Kawesqar language in the south of Chile have a genitive marker $-s$ on the dependent noun.

The predominant constituent order in Quechuan and Aymaran is subject/actorobjecttransitive verb (SOV), although there is some freedom. In dependent clauses and nominalized clauses the orders SOV converb and SOV nom are compulsory. In noun phrases a modifier precedes its head. Although there are few studies of constituent order in the other Andean languages, the rule that a modifier must precede its head in noun phrases is generally adhered to. There is much variation, however, with regard to the position of the adjective. In Colombia, except in its extreme south, most languages place the adjective after the noun it modifies. In northern Chile and northern Argentina, there was a belt of languages that did so as well (Atacameno, possibly Diaguita, Lule, Santiago del Estero Quechua); e.g. Atacameno puri lari [water red] 'red water' against Quechuan puka yaku [red water] 'red water'.

Validation of information and data source marking (evidentiality) were initially treated as characteristic features of the Andean languages, Quechuan and Aymaran. Although these categories are encoded differently in both language groups, by means of constituent-bound affixes operating at the sentence level in Quechua and by a mix of discourse markers and verbal affixes in Aymaran, their presence is required in nearly every sentence. Thanks to the expansion of research on South American indigenous languages, it has become clear that the distinctions 
represented by these categories are part of a widespread phenomenon found in a large number of South American languages, if not in most (see Aikhenvald 2004).

A problem with evidential categories is that they have not always been properly recognized in grammars and linguistic descriptions, due to their unfamiliar and unexpected characteristics. Extensive systems of evidentials are found in the Tucanoan languages of Colombia and Brazil and in many other South American languages.

\section{camp_010.pod 613}

\section{7-10-12 14:21:11 -mu- mu}

Languages of the Middle Andes in areal-typological perspective 613

Double negation, consisting of a negative adverb and an extra discourse marker, is not only found in Quechuan and in Aymaran, but also in Amuesha (Arawakan), which has undergone much influence from Quechuan; e.g. Amuesha ama mwen-o [not want.3sUBJ-NEG] 'he/she does not want (it)' (Duff-Tripp 1997: 128) and Quechuan mana muna- $n-c ̌ c u$ [not want-3suBJ-NEG] 'he/she does not want (it)' 49. This is yet another areal feature that spills over to the Andean eastern slopes in Central Peru. (For other examples see Campbell typology, this volume.) The numeral systems of the Andean languages stand out by their consistent decimal structure. The major languages of the Andes all have such a system, whereas the languages of the Amazonian region seldom have more than three true numerals. It is one of the major points of distinction between the languages of the Andean highlands and the Amazonian languages. Most of the numeral systems found in the Andes do not contain terms that can be related to terms in other languages, nor is it possible to establish clear etymologies for them. Aymaran also has a decimal system, but it clearly features a broken down five-term system complemented with terms borrowed from Quechuan (Cerron-Palomino 2000: 199).

\section{External distribution of typological features found in Andean languages other than Quechuan and Aymaran}

To complete this overview and finalize this chapter we may just mention a few typological characteristics found in other Andean languages. Due to the absence or shortage of documentation on most of these languages, only a few characteristics can be mentioned.

Numeral classifiers or measure terms were found in Mochica and in Cholon.

By their function they resemble the numeral classifiers found in Tsafiki (Barbacoan), in Cuna (Chibchan), and in Mayan languages, rather than the so-called Amazonian classifiers known from the literature (Derbyshire and Payne 1990). 
The Mochica classifier system is furthermore exceptional in that it counts tens and hundreds rather than individual units.

A distinction between possessed and non-possessed nouns was found in Mochica and in Atacameno (e.g. Atacameno possessed $c$ 'ei-ya versus non-possessed $c$ 'ei 'name' in is-c 'ei-ya 'your name'). It connects these languages with many similar cases in Mesoamerica and in the Amazonian lowlands of South America (including the pre-Andine Arawakan languages).

An elaborate gender system is found in the Uru-Chipayan languages in combination with a weakly developed system of personal pronominal marking. In Chipaya, a robust gender agreement appears to compensate for the relative lack of explicitness in subject and object marking. Grammatical gender is otherwise not found in the Andes, except to a limited extent in Paez (Colombia). Gender distinctions play a role in languages east of the Andes, for instance, in Arawakan, AraSetzerin: delete FN 49???

\section{camp_010.pod 614}

\section{7-10-12 14:21:11 -mu- mu}

614 Willem F.H. Adelaar

wan, and Chapacuran languages, in Bora, Cholon, Chiquitano, Moseten, Tehuelche and Yaruro. However, true gender agreement systems, such as found in Arawan and Arawakan languages and in Uru-Chipayan, are not frequent.

Morphological passive exists in Mochica in several formations. Mochica also has a special case marker that is affixed to the noun referring to the agent of a passive construction. The frequent use of the passive construction in Mochica is reminiscent of the Yucatecan and Cholan (Mayan) languages in Meso-America, where passive constructions in which the agent can be explicitly indicated are not uncommon either. A morphological and probably recently formed (agentless) passive is also found in Mapuche. Apart from these cases, explicit passive is absent from most of the Andean region, though it is found in other parts of South America. Lexical prefixes related to shape or instrument are found in Esmeraldeno (with nouns) and in Lule, Jebero (Cahuapanan) and Panoan languages (with verbs). The geographical distribution is too diffuse to uncover a pattern.

Insofar as case is concerned, Mapuche is exceptional in that it only has one frequently used case postposition ( $m e w$ ), which indicates oblique case. Instead, it indicates most of its sentence-internal relations through verbal morphology. 
Rudimentary case systems are also found in the Arawakan languages. Systems in which case relations are indicated by means of inflected prepositions or postpositions are found in Chiquitano, in Guajiro (Arawakan) and in the Cariban languages.

They are clearly not native to the Andes.

\section{Notes}

1 Writing this chapter was made possible thanks to the support of the Research Center of Linguistic Typology of LaTrobe University (Victoria, Australia). In this chapter abbreviations are avoided. Nevertheless, the following abbreviations have been used: $\mathrm{C}$ consonant, GEN genitive, NEG negative, NOM nominalization, O or OBJ object, POss possessive, $S$ or sUBJ subject, $V$ verb (predicate) or vowel, 1/2/3 first, second, third person.

2 The term Central Andes would be too restrictive in this context because it is often used for referring to the Andean highlands located in the central part of Peru.

3 The coastal valley site of Caral has been highlighted as a leading center from that period (Shady and Kleihege 2008; see also Moseley 2001: 112-127).

4 This observation holds for the Chumbivilcas language in the south-west of the department of Cuzco and the so-called 'outer languages' or hahuasimi in the southern part of the department of Ayacucho.

5 Our preference for the term Aymaran is motivated in Adelaar with Muysken (2004: 170).

The addition of the ending '-(a) $r$ ' is meant to indicate that this language family comprises several languages, of which Aymara is the principal one.

6 In subsequent publications, Torero introduced alternative terminologies for his subgroups, of which the version in his final work (Torero 2002) is as follows: Quechua I is rebaptized as Waywash, divided into a northern group, Waylay, and a southern group, Wankay. Quechua IIB and IIC are jointly referred to as Chinchay. Quechua IIA is called

\section{camp_010.pod 615}

\section{7-10-12 14:21:11 -mu- mu}

Languages of the Middle Andes in areal-typological perspective 615

Limay, and the whole of Quechua II is referred to as Yungay. The term Chinchay, in particular, is now frequently used in writings referring to the expansion of Quechuan.

7 The translation 'hill' for maca is circumstantial, hence tentative (Torero 2002: 242).

8 Quilter et al. (2010) report the discovery of a list of numerals from an unidentified language, which was found in the ruins of a church at Magdalena de Cao near the mouth of the Chicama river. The language at issue may have been Quingnam or the Fisherman's language (if not identical).

9 The name Jequetepeque is from Mochica. According to Torero (1986), Pacasmayo is a Quechua deformation of Quingnam Pacatnamu based on folk etymology.

10 There is a modern interpretative edition of the colonial Lule and Tonocote grammar, with an introductory essay by Raoul Zamponi (Maccioni 2008). 
$11 \mathrm{~A}$ case of an alleged external connection that may eventually be looked at again is Stark's (1968) proposal of a genetic link between Mochica and the Mayan languages. 12 A radical position against the common origin option is taken by Hardman (1985), who rejects the possibility of a common ancestor within the Americas. At the other end, Orr and Longacre (1978) defend the idea of a common origin by treating most of the borrowed lexicon as inherited and by reconstructing an inflated Quechuan-Aymaran protophonology meant to account for all the diversity found today.

13 In the current Aymara orthography this verb is written as jala-

14 In relation to the Cholon language, Torero (2002: 160) uses the expression "un quechua por armar" ('a Quechua to be put together'), suggesting that Pre-Proto-Quechua may have had the structure of a language with prefixes such as Cholon. 15 Suffixation is the dominant morphological device in many languages of the Andean region. Most languages, however, have at least a few prefixes. Quechuan and Aymaran have none.

16 Unlike in many other languages, aspect in Quechuan and Aymaran is strictly separated from tense and mood. Portmanteau suffixes combining aspect and number are found in Central Peruvian Quechuan varieties.

17 In the Aymaran languages all roots end in a vowel, at least underlyingly.

18 In Constenla's (1991) study of the languages of the so-called Area Intermedia, situated north of the Middle Andean area, accusative case marking is mentioned as a specific feature of the Middle Andes and some of the languages at its northern fringe.

19 The qualification of the personal reference system in terms of four persons defined by the (non)inclusion of speaker and addressee can be attributed to Hardman (1978). 20 An example is the verbal suffix - $m u$ - in Quechua as compared to -ni-in Aymara. Both affixes combine the meanings of 'motion towards the speaker or to a place the speaker has in mind' (with verbs of motion) and 'action performed in a place removed from the speaker' (with verbs of non-motion). Although frequent in Aymara, -ni-(or any equivalent) appears to be absent or obsolete in Jaqaru.

21 The term "transition" stems from the Peruvian colonial grammar tradition.

22 Coler-Thayer (2010) reports the existence in Moquegua (Peru) of an Aymara dialect that lacks a vowel length distinction and in which the verbalizing element is zeromarked. 23 Some Quechuan dialects of the Yauyos area (Peru) may have copied the homonymy of the genitive and locative marker from Aymaran (Cerron-Palomino 2000: 209); they have -pa for both functions (Taylor 1994).

24 In the literature on Quechua the mirative has been referred to as the sudden discovery tense (Adelaar 1977) or as a narrative past.

\section{camp_010.pod 616}

\section{7-10-12 14:21:11 -mu- mu}


616 Willem F.H. Adelaar

25 Jaqaru also has a series of alveolar affricates and a series of palatalized alveolars. They can probably be attributed to innovations.

26 Except in dialects heavily influenced by Aymara, such as Puno Quechua, where borrowed affixes preserve their glottalized and aspirated consonants (Adelaar 1987).

27 Cerron-Palomino (2000) does not reconstruct the velar nasal as one of the phonemes of Proto-Aymaran.

28 For an overview of such similarities, which were collected in search of a possible genetic link between Quechuan and Aymaran avoiding the obvious borrowings, see Campbell (1995).

29 Jaqaru pac aka may also be a secondary loan from Quechuan, like several other Jaqaru numerals.

$30 \mathrm{~A}$ previous attempt at detecting linguistic areas including the Middle Andes is found in Torero (2002: 511-544). For a study of the Area Intermedia, which borders on the Middle Andes to the north, see Constenla Umana (1991).

31 A similar distribution for mid vowels is found in Santiago del Estero Quechua, where vowel lowering is conditioned by an adjacent uvular or $r$.

32 Clairis (1977: 381-5) analyzes Kawesqar as tri-vocalic, but Aguilera's (1978, 1997, 1999) publications feature a more extensive vowel system for that language. For Tehuelche en Teushen see Fernandez Garay (1998) and Viegas Barros (2005).

33 We are referring to Bridges's work on Yahgan (Bridges 1894), not to recent recordings.

34 One of the two Cholon roots brought forward as containing a uvular stop by Torero is $<$ col> 'to die'. Observe the similarity with the Culli word for 'to die', which could be significant if the two languages were somehow related. The similarity with Quechuan qulyu- 'to die out', 'to be lost' is also suggestive.

35 Cerron-Palomino (2006: 38-39) observes that the Chipaya uvulars do not trigger vowel lowering, as in the tri-vocalic languages Quechua and Aymaran. This may also apply to some of the other languages mentioned here.

36 In Jebero, glottalization is limited to a velar stop $(k)$ and an atypical rhotic $(r)$. It is presumably the result of relatively recent changes (Valenzuela, forthcoming).

37 Note that Lule had a set of instrumental prefixes, as is also the case in Cahuapanan and Panoan languages. Esmeraldeno had shape-based classifiers as prefixes.

38 For degrammaticalization see Norde (2009). Note that degrammaticalization is used here as a gradual notion to the extent that possessive modifiers are still grammatical markers but less integrated with the nominal base than prefixes would be.

39 The phonetic notation used here is tentative because the sources for Puquina do not permit an exact rendering of its sounds. Note that the consonant weakening observed in po=wakas does not apply to all nouns.

40 Torero rejects the term passive for the construction at issue and prefers the term inverse 
(as opposed to direct).

41 The Mochica verbal subject markers are mobile elements. They can occur as suffixes on the verb or as clitics on a lexical element that precedes the verb. By contrast, tense markers (except for future tense) stay with the verb base as suffixes.

42 For the term post-base see Payne (1990: 231).

43 The Jebero verb is not exclusively suffixing. It also has a set of instrumental prefixes.

44 Note, however, that Goajiro (Arawakan), with no contact with Middle Andean languages, also uses more than a 100 suffixes, many of them doubtlessly verbal derivational (Alvarez 1994: 39). A similar situation holds for Matacoan languages (Campbell, personal communication).

\section{camp_010.pod 617}

\section{7-10-12 14:21:11 -mu- mu}

Languages of the Middle Andes in areal-typological perspective 617

45 With the exception of the 1subj > 2obj combination in the Quechua II varieties.

46 The same holds for the Tupi-Guaranian languages.

47 Tupi-Guaranian uses the dative/locative marker -pe/-me on animate objects.

48 Torero (2002: 143) mentions an extinct Aymaran variety in which the possessed was not marked for person. This is necessarily the case in Ecuadorian Quechua, where there are no possessive markers anymore.

\section{References}

Adelaar, Willem F. H.

1977 Tarma Quechua. Grammar, Texts, Dictionary. Lisse: Peter de Ridder.

Adelaar, Willem F. H.

1987 Aymarismos en el quechua de Puno. Indiana 11: 221-233. Berlin: Gebr. Mann.

Adelaar, Willem F. H.

1996 La nasal velar en el aymara y en el jaqaru. Opcion 1 (19): 5-19.

Adelaar, Willem F. H.

2000 Propuesta de un nuevo vinculo genetico entre dos grupos linguisticos indigenas de la Amazonia occidental: Harakmbut y Katukina. In: L. Miranda Esquerre (ed.), Actas del I Congreso de Lenguas indigenas de Sudamerica (Lima, 4-6 August 1999), Volume 2, 219-236. Lima: Universidad Ricardo Palma, Facultad de Lenguas Modernas.

Adelaar, Willem F. H.

2006 The Quechua impact in Amuesha, an Arawak language of the Peruvian Amazon.

In: A. Y. Aikhenvald and R. M. W. Dixon (eds.), Grammars in Contact.

A Cross-Linguistic Typology, 290-312. Oxford: Oxford University Press.

Adelaar, Willem F. H.

2009 Inverse markers in Andean languages: A comparative view. In: W. L. Wetzels 
(ed.), The Linguistics of Endangered Languages. Contributions to Morphology

and Morpho-Syntax, 171-185. Utrecht: LOT.

Adelaar, Willem F. H.

Forthcoming Cajamarca Quechua and the expansion of the Huari state. In: D. Beresford-

Jones and P. Heggarty (eds.), Archaeology and Language in the Andes.

Adelaar, Willem F. H. and Simon C. van de Kerke

2009 Puquina. In: M. Crevels and P. Muysken (eds.), Lenguas de Bolivia, Volume 1, 125-146. La Paz: Plural editores.

Adelaar, Willem F. H. with the collaboration of Pieter C. Muysken

2004 The languages of the Andes. Cambridge, UK: Cambridge University Press.

Aguilera Faundez, Oscar E.

1978 Lexico kawesqar-espanol espanol-kawesqar (Alacalufe septentrional). Boletin

de Filologia de la Universidad de Chile XXIX: 7-149.

Aguilera Faundez, Oscar E.

1997 La expresion del tiempo en kawesqar. Onomazein 2: 269-304.

Aguilera Faundez, Oscar E.

1999 En torno al orden de las palabras en kawesqar: componentes morfologicos del verbo. Onomazein 4: 301-320.

\section{camp_010.pod 618}

\section{7-10-12 14:21:11 -mu- mu}

618 Willem F.H. Adelaar

Aikhenvald, Alexandra Y.

2004 Evidentiality. Oxford: Oxford University Press.

Alexander-Bakkerus, Astrid

2005 Eigthteenth-Century Cholon. Utrecht: LOT.

Alexander-Bakkerus, Astrid (ed.)

2007 Pedro de la Mata, arte de la lengua cholona (1748). Madrid: Iberoamericana.

Frankfurt am Main: Vervuert.

Alvarez, Jose

1994 Estudios de linguistica guajira. Maracaibo: Secretaria de Cultura de la Gobernacion del Estado Zulia.

Andrade Ciudad, Luis

2009 De telares y sufijos: sobre el problema de la frontera nortena de la extinta lengua culle. Paper presented at the VIIth International Symposium on Archaeology

(28-30 August), Pontificia Universidad Catolica del Peru, Lima.

Bendor-Samuel, John T.

1961 The verbal piece in Jebero. Supplement to Word 17. Monograph No. 4.

Beresford-Jones, David G. and Paul Heggarty 
Forthcoming What role for language prehistory in redefining archaeological 'culture'? A case-study on new horizons in the Andes. In: B. Roberts and M. van der Linden (eds.), Investigating Archaeological Cultures: Material Culture, Variability and Transmission. New York: Springer.

Bouysse-Cassagne, Therese

1975 Pertenencia etnica, status economico y lenguas en Charcas a fines del siglo XVI. In: N. D. Cook (ed.), Tasa de la visita general de Francisco de Toledo, 312-328. Lima: Universidad Nacional Mayor de San Marcos.

Bravo, Domingo A. 1993 El quichua santiagueno es el quichua argentino. In: P. Viegas Barros and N. N. Stell (eds.), Actas Primeras Jornadas de Linguistica Aborigen (Buenos Aires, 6-7 October), 35-46. Buenos Aires: Universidad de Buenos Aires, Facultad de Filosofia y Letras, Instituto de Linguistica.

Bridges, Thomas 1894 A few notes on the structure of Yahgan. The Journal of the Anthropological Institute of Great Britain and Ireland 23: 53-80.

Cabral, Anna Suely Arruda Camara 1995 Contact-induced language change in the Western Amazon: The non-genetic origin of the Kokama language. Ph.D. dissertation, University of Pittsburgh. Cabral, Anna Suely Arruda Camara 2007 New observations on the structure of Kokama/Omagwa, a language of the border region in Brazil, Peru and Colombia. In: L. Wetzels (ed.), Language Endangerment and Endangered Languages, 365-379. Leiden: CNWS Publications. Campbell, Lyle R.

1995 The Quechumaran hypothesis and lessons for distant genetic comparison.

Diachronica 12: 157-200.

Carrera Daza, Fernando de la 1939 Arte de la lengua yunga. Edited by R. Altieri. Tucuman: Universidad de Tucuman, Instituto de Antropologia. First published [1644].

\section{camp_010.pod 619}

\section{7-10-12 14:21:11 -mu- mu}

Languages of the Middle Andes in areal-typological perspective 619

Cerron-Palomino, Rodolfo

2000 Linguistica aimara. Cuzco: Centro "Bartolome de Las Casas".

Cerron-Palomino, Rodolfo

2006 El chipaya o la lengua de los hombres del agua. Lima: Fondo Editorial de la

Pontificia Universidad Catolica del Peru.

Cerron-Palomino, Rodolfo 
2008 Quechumara. Estructuras paralelas del quechua y del aimara. La Paz: Universidad Mayor de San Simon, PROEIBAndes, Plural Editores. First published La

Paz: CIPCA [1994].

Chirinos Rivera, Andres

2001 Atlas linguistico del Peru. Lima: Ministerio de Educacion. Cuzco: Centro

"Bartolome de las Casas".

Clairis, Christos

1987 El qawasqar. Linguistica fueguina: teoria y descripcion. (Estudios Filologicos:

Anejo 12 [1985].) Valdivia: Universidad Austral de Chile.

Cobo, Bernabe

1890-1895 Historia del Nuevo Mundo. Edited by M. Jimenez de la Espada. Sevilla:

E. Rasco. First published [1653].

Coler-Thayer, Matthew L.

2010 A grammatical description of Muylaq' Aymara. Ph.D. dissertation, Free University

of Amsterdam.

Constenla Umana, Adolfo

1991 Las lenguas del Area Intermedia: Introduccion a su estudio areal. San Jose:

Editorial de la Universidad de Costa Rica.

Crevels, Mily and Pieter C. Muysken (eds.)

2009 Lenguas de Bolivia, Volume 1. La Paz: Plural editores.

Curnow, Timothy Jowan and Anthony J. Liddicoat

1998 The Barbacoan languages of Colombia and Ecuador. Anthropological Linguistics

40 (3): 384-408.

Danielsen, Swintha

2007 Baure. An Arawak language of Bolivia. Leiden: CNWS Publications.

Danielsen, Swintha

Forthcoming The argument encoding system in Baure and other Southern Arawak languages.

International Journal of American Linguistics.

DeLancey, Scott

1997 Mirativity: The grammatical marking of unexpected information. Linguistic

Typology 1: 33-52.

Derbyshire, Desmond C. and Doris L. Payne

1990 Noun classification systems of Amazonian languages. In: D. L. Payne (ed.),

Amazonian Linguistics: Studies in Lowland South American Languages,

243-271. Austin: University of Texas Press.

Duff-Tripp, Martha

1997 Gramatica del idioma yanesha' (amuesha). Lima: Ministerio de Educacion

and Instituto Linguistico de Verano.

Faller, Martina 
2002 Semantics and pragmatics of evidentials in Cuzco Quechua. Ph.D. dissertation, Stanford University.

\section{camp_010.pod 620}

\section{7-10-12 14:21:11 -mu- mu}

620 Willem F.H. Adelaar

Fernandez Garay, Ana V.

1998 El tehuelche. Una lengua en vias de extincion. (Estudios filologicos. Anejo 15.)

Valdivia: Universidad Austral de Chile, Facultad de Filosofia y Humanidades.

Floyd, Rick

1999 The Structure of Evidential Categories in Wanka Quechua. Dallas: SIL and the University of Texas at Arlington.

Furlong, Guillermo

1941 Entre los Iules de Tucuman. Buenos Aires: Talleres Graficos "San Pablo".

Gnerre, Maurizio

1975 L'utilizzazione delle fonti documentarie dei secoli XVI e XVII per la storia linguistica

Jibaro. In: E. Cerulli and G. Della Ragione (eds.), Atti de/ XL Congresso

Internazionale degli Americanisti (Rome and Genoa, 3-12 September

1972), Volume 3, 79-86. Genoa: Tilgher.

Hannss, Katja

2008 Uchumataqu: The Lost Language of the Urus of Bolivia. A Grammatical Description

of the Language as Documented between 1894 and 1952. Leiden:

CNWS Publications.

Hardman, Martha J.

1978 Jaqi. The linguistic family. International Journal of American Linguistics 44

(2): 146-153.

Hardman, Martha J.

1985 Aymara and Quechua: Languages in contact. In: H. E. Manelis Klein and

L. R. Stark (eds.), South American Indian Languages: Retrospect and Prospect, 617-643. Austin: University of Texas Press.

Hardman, Martha J.

2000 Jaqaru. Munich: LINCOM Europa.

Hartmann, Roswith

1979 .Quechuismo preincaico en el Ecuador? Ibero-amerikanisches Archiv 5 (3):

267-299.

Haude, Katharina

2006 A grammar of Movima. Ph.D. dissertation, Radboud University, Nijmegen.

Zetten: Manta.

Heggarty, Paul 
2005 Enigmas en el origen de las lenguas andinas: aplicando nuevas tecnicas a las incognitas por resolver. Revista Andina 40: 9-80.

Howard, Rosaleen

2007 Por los linderos de la lengua: Ideologias linguisticas en los Andes. Lima: Instituto de Estudios Peruanos, Instituto Frances de Estudios Andinos, Fondo

Editorial de la Universidad Catolica del Peru.

Isbell, William $\mathrm{H}$.

2009 The archaeology of Wari and the dispersal of Quechua. Paper presented the VIlth International Symposium on Archaeology. 28-30 August. Lima: Pontificia

Universidad Catolica del Peru.

Jijon y Caamano, Jacinto

1940-1945 El Ecuador interandino y occidental antes de la conquista espanola. Quito:

Editorial Ecuatoriana.

\section{camp_010.pod 621}

\section{7-10-12 14:21:11 -mu- mu}

Languages of the Middle Andes in areal-typological perspective 621

Jimenez de la Espada, Marcos (ed.)

1965 Relaciones geograficas de Indias: Peru. In: Biblioteca de Autores Espanoles, Volumes 183-185. Madrid: Atlas.

Kerke, Simon C. van de

2009 Leko. In: Mily Crevels and Pieter C. Muysken (eds.), Lenguas de Bolivia, Volume 1, 287-331. La Paz: Plural editores.

Landerman, Peter N.

1991 Quechua dialects and their classification. Ph.D. dissertation, University of California, Los Angeles.

Loukotka,C` estmir 1968 Classification of South American Indian languages. Edited by J. Wilbert. Los Angeles: University of California (UCLA), Latin American Center.

Maccioni, Antonio

2008 Arte y Vocabulario de la lengua Lule y Tonocote. Edited by R. Badini, T. Deonette and S. Pineider. Cagliari: Centro di Studi Filologici Sardi.

Machoni de Cerdena, Antonio

1732 Arte y vocabulario de la lengua lule y tonocote. Madrid: Herederos de Garcia Infanzon.

McQuown, Norman A.

1955 The indigenous languages of Latin America. American Anthropologist, NS,

57: 501-570.

Mann, Charles 
2005 1491. New Revelations of the Americas Before Columbus. New York: Alfred

A. Knopf

Mannheim, Bruce

1991 The Language of the Inka since the European Invasion. Austin: University of Texas Press.

Martinez Companon, Baltasar Jaime

1985 Trujillo del Peru en el siglo XVIII, Volume 2. Madrid: Ediciones Cultura

Hispanica. First published [1782-1790].

Middendorf, Ernst W.

1892 Das Muchik oder die Chimu-Sprache mit einem Anhang uber die Chibcha-

Sprache. In: Die einheimischen Sprachen Perus, Volume 6. Leipzig: F. A. Brockhaus.

Moseley, Michael

2001 The Incas and their Ancestors: The Archaeology of Peru. London: Thames \&

Hudson.

Mosonyi, Esteban Emilio

1966 Morfologia del verbo yaruro: Estudio de los sufijos personales. Caracas: Universidad Central de Venezuela, Consejo de Desarrollo Cientifico e Humanistico.

Norde, Muriel

2009 Degrammaticalization. Oxford: Oxford University Press.

Ore, Luis Jeronimo de

1607 Rituale seu Manuale Peruanum. Naples: Giacomo Carlino and Costantino

Vitale.

Orr, Carolyn J. and Robert E. Longacre

1978 Proto Quechumaran. Language 44: 528-555.

\section{camp_010.pod 622}

\section{7-10-12 14:21:11 -mu- mu}

622 Willem F.H. Adelaar

Overall, Simon E.

2007 A grammar of Aguaruna. Ph.D. dissertation, La Trobe University, Bundoora,

Australia.

Parker, Gary J.

1963 La clasificacion genetica de los dialectos quechuas. Revista del Museo Nacional

32: 241-252.

Payne, David L.

1991 Maipuran (Arawak). In: D. C. Derbyshire and G. K. Pullum (eds.), Handbook

of Amazonian Languages, Volume 3, 355-499. Berlin/New York: Mouton de

Gruyter.

Payne, Doris L. (ed.) 
1990 Morphological characteristics of Lowland South American Languages. In:

D. L. Payne (ed.), Amazonian Linguistics. Studies in Lowland South American

Languages, 213-241. Austin: University of Texas Press.

Payne, Judith

1989 Lecciones para el aprendizaje del idioma asheninca. Instituto Linguistico de Verano, Ministerio de Educacion, Yarinacocha (Peru).

Paz y Mino, Luis $\mathrm{T}$.

1940-1942 Lenguas indigenas del Ecuador. Boletin de la Academia Nacional de Historia

20 (56): 161-78, La lengua pasto; 21 (57): 28-52, La lengua kara; 21

(58): 145-170, La kito o panzaleo; 22 (59): 42-74, La lengua puruguay.

Paz y Mino, Luis T.

1961 Lenguas indigenas del Ecuador. Boletin de la Academia Nacional de Historia

43 (97): 5-16.

Poblete Mendoza, Maria Teresa and Adalberto Salas

1999 Fonemas yamana (yagan). Estructura fonologica de la palabra. Revista de Linguistica

Teorica y Aplicada 37: 107-122.

Quilter, Jeffrey, Marc Zender, Karen Spalding, Regulo Franco Jordan, Cesar Galvez Mora

and Juan Castaneda Murga2010Traces of a lost language and number system

discovered on the North Coast of Peru. American Anthropologist 112 (3):

357-369.

Ringmacher, Manfred and Ute Tintemann (eds.)

Forthcoming Wilhelm von Humboldt Sudamerikanische Grammatiken. (Wilhelm-von-

Humboldt-Ausgabe der Berlin-Brandenburgischen Akademie der Wissenschaften

5.) Paderborn: Schoningh.

Salas, Adalberto

1992 El mapuche o araucano: Fonologia, gramatica y antologia de cuentos. Madrid:

Editorial MAPFRE.

Salas, Jose Antonio

2002 Diccionario mochica-castellano castellano-mochica. Lima: Universidad de

San Martin de Porres, Escuela Profesional de Turismo y Hoteleria.

Schjellerup, Inge, Mikael Kamp Sorensen, Carolina Espinoza, Victor Quipuscoa and Victor

Pena

2003 The Forgotten Valleys: Past and Present in the Utilization of Resources in the

Ceja de Selva, Peru. Copenhagen: The National Museum of Denmark.

Schumacher, Achim, Nathalie Bocker and Francisca Condori Mollo

2009 Chholo. In: Mily Crevels and Pieter C. Muysken (eds.), Lenguas de Bolivia,

Volume 1, 117-123. Le Paz: Plural editors.

\section{camp_010.pod 623}




\section{7-10-12 14:21:11 -mu- mu}

Languages of the Middle Andes in areal-typological perspective 623

Shady, Ruth and Christopher Kleihege

2008 Caral. The first civilization in the Americas. Lima: Logicorp S.A., Proyecto Especial

Arqueologico Caral-Supe/INC and Universidad de San Martin de Porres.

Smeets, Ineke

2007 A Grammar of Mapuche. Berlin/New York: Mouton de Gruyter.

Stark, Louisa R.

1968 Mayan affinities with Yunga of Peru. Ph.D. dissertation, New York University.

Taylor, Gerald

1984 Yauyos: un microcosmo dialectal quechua. Revista Andina 2 (1): 121-146.

Taylor, Gerald

1990 La lengua de los antiguos chachapuyas. In: R. M. Cerron-Palomino and

G. Solis Fonseca (eds.), Temas de linguistica amerindia, 121-139. (Actas del

Primer Congreso Nacional de Investigaciones Linguistico-Filologicas. Lima,

November 1987.) Lima: CONCYTEC and Deutsche Gesellschaft fur technische

Zusammenarbeit (GTZ).

Taylor, Gerald

1994 Estudios de dialectologia quechua (chachapoyas, ferrenafe, yauyos). Chosica:

Editorial Universitaria Universidad Nacional de Educacion.

Torero, Alfredo A.

1964 Los dialectos quechuas. Anales Cientificos de la Universidad Agraria 2 (4):

446-478.

Torero, Alfredo A.

1972 Linguistica e historia de la sociedad andina. In: A. Escobar (ed.), El reto del

multilinguismo en el Peru, 46-106. Lima: Instituto de Estudios Peruanos.

Torero, Alfredo A.

1986 Deslindes linguisticos en la costa norte peruana. Revista Andina 4 (3): 523-548.

Torero, Alfredo A.

1987 Lenguas y pueblos altiplanicos en torno al siglo XVI. Revista Andina 5 (2):

329-405.

Torero, Alfredo A.

1989 Areas toponimicas e idiomas en la sierra norte peruana. Un trabajo de recuperacion linguistica. Revista Andina 7 (1): 217-257.

Torero, Alfredo A.

2002 Idiomas de los Andes. Lima: Instituto Frances de Estudios Andinos e Editorial Horizonte.

Tovar, Antonio 
1961 Catalogo de las lenguas de America del Sur. Buenos Aires: Editorial Sudamericana.

Vaisse, Emilio, Felix Hoyos and Anibal Echeverria y Reyes

1896 Glosario de la lengua atacamena. Santiago de Chile: Imprenta Cervantes.

Valdivia, Luis de

1887 Arte y gramatica general de la lengua que corre en todo el Reyno de Chile,

con un vocabulario y confessionario. Leipzig: B. G. Teubner. First published

Lima: Francisco del Canto [1606].

Valenzuela Bismarck, Pilar M.

Forthcoming Contribuciones para la reconstruccion del Proto-Cahuapana: comparacion lexica y gramatical de las lenguas jebero y chayahuita.

\section{camp_010.pod 624}

\section{7-10-12 14:21:11 -mu- mu}

624 Willem F.H. Adelaar

Veerman-Leichsenring, Annette

1991 Gramatica del Popoloca de Metzontla (con vocabulario y textos). Amsterdam:

Rodopi.

Viegas Barros, J. Pedro

2005 Voces en el Viento. Raices linguisticas de la Patagonia. Buenos Aires: Mondragon.

Voort, Hein van der

2004 A Grammar of Kwaza. Berlin/New York: Mouton de Gruyter.

Wise, Mary Ruth

1976 Apuntes sobre la influencia inca entre los amuesha: factor que oscurece la clasificacion

de su idioma. Revista del Museo Nacional 42: 355-366.

Zevallos Quinones, Jorge

1992 Los cacicazgos de Trujillo. Trujillo, Peru: Grafica Cuatro S.A.

Zuniga, Fernando

2000 Mapudungun. Munich: LINCOM Europa. 